University of Wollongong

Research Online

Faculty of Engineering and Information

Faculty of Engineering and Information

Sciences - Papers: Part B

Sciences

2019

Experimental investigations on the behavior of GFRP bar reinforced HSC and UHSC beams under static and impact loading

M W. Goldston

Enstruct

Alex M. Remennikov

University of Wollongong, alexrem@uow.edu.au

Zein Saleh

University of Wollongong, zs492@uowmail.edu.au

M Neaz Sheikh

University of Wollongong, msheikh@uow.edu.au

Follow this and additional works at: https://ro.uow.edu.au/eispapers1

Part of the Engineering Commons, and the Science and Technology Studies Commons

Research Online is the open access institutional repository for the University of Wollongong. For further information contact the UOW Library: research-pubs@uow.edu.au 


\title{
Experimental investigations on the behavior of GFRP bar reinforced HSC and UHSC beams under static and impact loading
}

\author{
Abstract \\ This paper presents an experimental investigation into the behavior of Glass Fiber-Reinforced Polymer \\ (GFRP) bar reinforced high strength concrete and ultra-high strength concrete beams. In total, twelve \\ GFRP bar reinforced concrete beams (GFRP-RC beams) were constructed and tested. Six GFRP-RC \\ beams were tested under static loading. Higher strength concrete was found to influence the overall \\ behavior of GFRP-RC beams under static loading in terms of load carrying capacity, deflection, and post- \\ cracking bending stiffness. Six GFRP-RC beams were tested under impact loading at various levels of \\ impact energy. The GFRP-RC beams displayed a shift in the failure mode (from shear failure to flexure \\ failure) as a result of the use of ultra-high strength concrete under impact loading. \\ Disciplines \\ Engineering | Science and Technology Studies

\section{Publication Details} \\ Goldston, M. W., Remennikov, A., Saleh, Z. \& Sheikh, M. Neaz. (2019). Experimental investigations on the \\ behavior of GFRP bar reinforced HSC and UHSC beams under static and impact loading. Structures, 22 \\ 109-123.
}


1 Experimental Investigations on the Behavior of GFRP bar Reinforced HSC and UHSC Beams under Static and Impact Loading

3

4

5

$6 \quad{ }^{1}$ Structural Engineer, Enstruct, 4/2 Glen St, Milsons point, NSW 2061, Australia

$7 \quad{ }^{2}$ Professor, School of Civil, Mining and Environmental Engineering, University of Wollongong, Australia.

8
M.W.Goldston ${ }^{1}$, A. Remennikov², Zein Saleh ${ }^{3}$, and M. Neaz Sheikh,,*

${ }^{3} \mathrm{Ph} . \mathrm{D}$. student, School of Civil, Mining and Environmental Engineering, University of Wollongong, Australia

${ }^{4}$ Associate Professor, School of Civil, Mining and Environmental Engineering, University of Wollongong, Australia

*Corresponding author (email: msheikh@uow.edu.au) 
ABSTRACT

This paper presents an experimental investigation into the behavior of Glass Fiber-Reinforced Polymer (GFRP) bar

21 reinforced high strength concrete and ultra-high strength concrete beams. In total, twelve GFRP bar reinforced

22 concrete beams (GFRP-RC beams) were constructed and tested. Six GFRP-RC beams were tested under static loading.

23 Higher strength concrete was found to influence the overall behavior of GFRP-RC beams under static loading in terms

24 of load carrying capacity, deflection, and post-cracking bending stiffness. Six GFRP-RC beams were tested under

25 impact loading at various levels of impact energy. The GFRP-RC beams displayed a shift in the failure mode (from

26 shear failure to flexure failure) as a result of the use of ultra-high strength concrete under impact loading.

27 Author Keywords: Reinforced Concrete; GFRP; Beams; Impact; High Strength Concrete; Ultra High Strength

28 Concrete

\section{Introduction}

31 Durability, corrosion resistance, and blast and impact resilience are the current requirements for high-performance

32 reinforced concrete (RC) structures. Understanding and modeling of concrete behavior under extreme environmental

33 loading conditions are essential for making RC structures safer and more efficient. In particular, the corrosion of

34 reinforcement can expedite the aging process and deterioration of the infrastructure. The aging and deterioration

35 process of the infrastructure may cause aesthetic problems together with significant financial implications resulting

36 from increased maintenance cost. Hence, it is an important challenge for structural engineers to design structures to

37 resist extreme loads in harsh environmental conditions.

38 To overcome corrosion related damage and deterioration, Fiber-Reinforced Polymer (FRP) bars are considered to be

39 an alternative option for reinforcing concrete structures as opposed to conventional steel reinforcement [1-3]. FRP

40 bars possess non-corrosive behavior, which makes it viable to reinforced concrete structures in coastal environments.

41 Furthermore, FRP bars have a high-strength to weight ratio, making it easy to transport on site. Commercially available

42 FRP bars include glass (Glass Fiber Reinforced Polymer, GFRP), carbon (Carbon Fiber Reinforced Polymer, CFRP),

43 aramid (Aramid Fiber Reinforced Polymer, AFRP) and basalt (Basalt Fiber Reinforced Polymer, BFRP). The FRP

44 bars are well known to have linear stress-strain behavior up until failure under uniaxial tension, with no or limited 
ductility, unlike the conventional steel reinforcement. Also, FRP bars have a low modulus of elasticity (e.g., 35 GPa -51 GPa, according to ACI [4]). FRP bars are relatively expensive compared to steel reinforcement. However, the

47 service life and durability of concrete structures reinforced with FRP bars are higher, resulting in a decrease in the overall maintenance costs. Previous experimental studies investigated the impact behaviour of RC beams reinforced with conventional steel reinforcement [5-21]. Three types of responses were observed: local response, global response, and a combination of

51 local and global response. Local failure modes of steel RC beams under impact have been termed as being scabbing, which results in the spalling of the concrete cover, penetration, and diagonal shear cracking around the contact zone.

53 Local response is typically referred as a shear "plug" type, even for flexural-critical steel RC beams [12] or a localized 54 dynamic punching shear failure [8, 22-25], which occurs at higher velocity impacts. In the local response, the majority of energy from the impact in the steel RC beams is dissipated around the impact area. A global response of the steel 56 RC beams represents bending and deformation responses of the beams. The behavior of steel RC beams under impact 57 loading has been reported as the combination of local and global responses (bending and deformation) [7]. However, the global response has been reported as the main concern for the steel RC beams subjected to impact loading [7]. The 59 influences of different parameters including impact velocity, impact energy, cracking response, and shear mechanisms 60 were investigated and static and impact failure modes of steel RC beams were compared in the literature. Also, the 61 previous studies were mostly limited to normal strength concrete (NSC) beams. Only a limited number of studies 62 examined the impact response of high strength concrete (HSC) beams reinforced with conventional steel 63 reinforcement [26-31]. A few studies reported that brittle shear failure occurs in HSC [32-36]. Although the behavior 64 of steel RC beams under impact loading was studied extensively, limited attention has been devoted on the 65 experimental investigation of the impact response of GFRP bar reinforcement concrete beams (GFRP-RC beams) 66 [37]. Goldston et al. [37] reported that flexural-critical GFRP-RC beams displayed a shear "plug” type of failure under 67 impact loading, which indicated the importance of shear mechanisms. It was also found that using high strength concrete and increasing the tensile reinforcement ratio, fewer inclined shear cracks occurred. However, from an 69 extensive literature review, it was found that no study has so far addressed the impact behavior of ultra-high strength 70 concrete (UHSC) (concrete compressive strength greater than $100 \mathrm{MPa}$ ) beams reinforced with GFRP bars [38]. It is 71 noted that concrete compressive strength above 100 MPa has been considered as UHSC in Vincent and Ozbakkaloglu 72 [39] and Ozbakkaloglu [40]. 
73 This paper investigates experimentally the static and impact responses of GFRP bar reinforced high strength concrete

74 (HSC) and ultra-high strength concrete (UHSC) beams. Three different GFRP tensile longitudinal reinforcement ratios

75 and two different grades of concrete were used. Under static loading, the influences of concrete strength and

76 reinforcement ratio on load-carrying capacity, deflection, crack pattern and failure mode of the GFRP-RC beams were

77 investigated. Under impact loading, the influences of impact energy on the dynamic midspan deflection, dynamic

78 strain in the GFRP reinforcement bars, crack patterns, and failure modes of GFRP-REC beam were investigated.

79

80

\section{Experimental Program}

\section{$81 \quad 2.1$ Material Properties}

82 A local company supplied the ready-mix concrete used in this study. Concrete cylinders with $100 \mathrm{~mm}$ diameter and

$83200 \mathrm{~mm}$ height were cast to measure the concrete compressive strength according to Australian Standard AS 1012.9

84 [41]. Table 1 provides the details of concrete mix designs for concrete of nominal compressive strengths of 80 MPa

85 and $120 \mathrm{MPa}$. The average compressive strengths of concrete at 28 days were $84.6 \mathrm{MPa}$ (for the nominal concrete

86 strength of $80 \mathrm{MPa}$ ) and 100.5 MPa (for the nominal concrete strength of $120 \mathrm{MPa}$ ), respectively. On the day of static

87 testing (day 62), the average compressive strengths of concrete were $95 \mathrm{MPa}$ (for the nominal concrete strength of 80

$88 \mathrm{MPa}$ ) and $117 \mathrm{MPa}$ (for the nominal concrete strength of $120 \mathrm{MPa}$ ). Three different diameters of sand-coated GFRP

89 reinforcement bars were used. The \#2S (Standard) bars had a nominal diameter of $6.35 \mathrm{~mm}$, \#3HM (High Modulus)

90 had a nominal diameter of $9.53 \mathrm{~mm}$, and \#4HM had a nominal diameter of $12.7 \mathrm{~mm}$. The tensile properties of the

91 GFRP reinforcement bars were determined by testing three specimens from each type of GFRP reinforcement bar

92 (\#2S, \#3HM and \#4HM). Average tensile strength $\left(f_{u}\right)$, modulus of elasticity $\left(E_{f}\right)$ and rupture strain $\left(\varepsilon_{f u}\right)$ using the

93 Instron 8033 universal testing machine were obtained according to ASTM [42]. The GFRP reinforcement bars were

94 loaded until failure at the rate of $1 \mathrm{~mm} / \mathrm{min}$. Strains in the bars were measured using a $100 \mathrm{~mm}$ extensometer attached

95 to the GFRP bars within the free length. The stress-strain behavior of the GFRP bars was found to be linear. All tensile

96 test specimens failed due to splitting and rupture of the GFRP fibers. For \#2S GFRP reinforcement bars, $f_{u}=$

$97732 \mathrm{MPa}, \varepsilon_{f u}=1.96 \%$ and $E_{f}=37.5 \mathrm{GPa}$. For \#3HM GFRP reinforcement bars, $f_{u}=1764 \mathrm{MPa}, \varepsilon_{f u}=3.18 \%$

98 and $E_{f}=55.6 \mathrm{GPa}$. For \#4HM GFRP bars, $f_{u}=1605 \mathrm{MPa}, \varepsilon_{f u}=3.30 \%$ and $E_{f}=48.6 \mathrm{GPa}$. 
Steel stirrups were used as shear reinforcement. Three $4 \mathrm{~mm}$ diameter steel reinforcement bar specimens were tested using the Instron 1343 universal testing machine, with a tensile capacity of $100 \mathrm{kN}$ according to ASTM [43]. The tensile test specimens were loaded at $0.2 \mathrm{~mm} / \mathrm{min}$ until necking. Mean yield strength, ultimate tensile strength and elastic modulus were measured as 583 MPa, 640 MPa and 200 GPa, respectively.

\subsection{Details of GFRP-RC Beams}

105 A total of twelve simply supported GFRP-RC beams were constructed and tested under static and impact loading. The experimental program consisted of two series of test specimens. The first series consisted of six GFRP-RC beams tested under static loading (S) (three-point bending) to investigate the influence of tensile GFRP reinforcement bars on the flexural behavior of beams. The test variables were the amount of tensile longitudinal reinforcement and the compressive strength of concrete. Three beams were constructed with concrete of $80 \mathrm{MPa}$ nominal compressive strength, and three beams were constructed with concrete of $120 \mathrm{MPa}$ nominal compressive strength. The parameters

111 investigated were load-deflection behavior, failure mode, energy absorption and strain in the concrete and GFRP 112 reinforcement bars. The second series consisted of six UHSC GFRP-RC beams tested under impact loading to 113 investigate the dynamic response of UHSC GFRP-RC beams. The six GFRP-RC beams under impact loading (I) were 114 constructed with the nominal concrete compressive strength of $120 \mathrm{MPa}$. Three beams had tensile longitudinal 115 reinforcement ratios $\left(\rho_{f}\right)$ of $1.0 \%$ and three other beams had $\rho_{f}$ of $2.0 \%$. The GFRP-RC beams were subjected to three different impact heights of the $580 \mathrm{~kg}$ drop hammer for specimens with $\rho_{f}=1.0 \%$ and $\rho_{f}=2.0 \%$. Based on

117 the test results of the energy absorption capacity (50\%, 75\% and 100\% energy absorption capacity) of the GFRP-RC

118 beams under static loading, the height of the drop hammer was calculated. Three beams with $\rho_{f}=1.0 \%$ were 119 subjected to drop hammer heights of $355 \mathrm{~mm}, 533 \mathrm{~mm}$ and $710 \mathrm{~mm}$. The three beams with $\rho_{f}=2.0 \%$ were subjected 120 to drop hammer heights of $550 \mathrm{~mm}, 825 \mathrm{~mm}$ and $1100 \mathrm{~mm}$. Test parameters investigated included dynamic midspan 121 deflection, dynamic bending resistance, dynamic strain in GFRP reinforcement bars, failure mode and crack patterns. 122 The GFRP-RC beams were $2400 \mathrm{~mm}$ long, $100 \mathrm{~mm}$ wide and $150 \mathrm{~mm}$ deep. The GFRP-RC beams were reinforced 123 with two GFRP bars in the tensile and two GFRP bars in the compressive region. The concrete clear cover was 15 $124 \mathrm{~mm}$ (from the outer surface of the steel stirrup to the tensile face of the GFRP-RC beams). The effective depths $(d)$ were calculated as $127.8 \mathrm{~mm}, 126.2 \mathrm{~mm}$ and $124.7 \mathrm{~mm}$ for beams with $\rho_{f}=0.5 \%, 1.0 \%$ and $2.0 \%$, respectively. The 

cages are shown in Fig. 1. A side view of the GFRP-RC beams is shown in Fig. 2.

128 The GFRP-RC beams were designed in accordance with ACI [4] to fail by both concrete crushing (over-reinforced), where the maximum usable compressive strain in the concrete $\left(\varepsilon_{c u}\right)$ is assumed as 0.003 and GFRP reinforcement rupture (under-reinforced). Design nominal moment capacities $\left(M_{n}\right)$ were calculated according to ACI [4] for the over and under-reinforced GFRP-RC beams. For GFRP-RC beams, the preferred design is over-reinforced, as the beam is assumed to be less brittle with an amount of pseudo-ductility. Under-reinforced GFRP-RC beams fail in a catastrophic way without warning. Two GFRP-RC beams were under-reinforced and ten GFRP-RC beams were over-reinforced according to ACI [4].

The GFRP-RC beams were labeled according to the series, nominal concrete strength, longitudinal reinforcement type, reinforcement ratio and type of loading. The arrangement is in the form of $\mathrm{A}-\mathrm{B}-\mathrm{C}-\mathrm{D}_{\mathrm{x}}$, where $\mathrm{A}$ is the nominal concrete compressive strength (80 MPa or $120 \mathrm{MPa}$ ), B is the GFRP reinforcement bar type (\#2S, \#3HM or \#4HM), C is the tensile GFRP longitudinal reinforcement ratio $\left(\rho_{f}=0.5 \%, 1.0 \%\right.$ and $\left.2.0 \%\right)$ and D is for the type of loading, (S for static loading and I for impact loading). For GFRP-RC beams under impact loading, the subscript (x) represents the height of the drop hammer in meters. For example, GFRP-RC beam 80-\#3HM-1.0-S was designed with the concrete compressive strength of $80 \mathrm{MPa}$ \#3HM GFRP reinforcement bars, $\rho_{f}=1.0 \%$ and tested under static loading. For GFRP-RC beam 120-\#4HM-2.0-I I.1. $_{\text {, }}$ the nominal concrete compressive strength was $120 \mathrm{MPa}$ \#4HM

143 GFRP reinforcement bars, $\rho_{f}=2.0 \%$ and was subjected to a $1.1 \mathrm{~m}$ drop hammer height under impact loading. Table

1442 provides a summary of the properties of the GFRP-RC beams including design nominal moment capacity, $M_{n}$ according to ACI [4], calculated using preliminary material properties obtained from experimental testing.

\section{Experimental Setup}

\subsection{Static Testing}

149 Test set-up for the GFRP-RC beams under static loading involved placing the beams between two steel I-beams with a clear span of $2000 \mathrm{~mm}$. The beam had a $200 \mathrm{~mm}$ overhang on each side. The beams were simply supported: a pin support at one end and a roller support at the other end. A $600 \mathrm{kN}$ hydraulic actuator anchored to a steel frame was

152 used to apply monotonic increasing loads on a steel circular plate positioned at the midspan. The hydraulic actuator 153 had a built-in transducer which captured the midspan deflection. The GFRP-RC beams were tested under the 
displacement controlled loading at a rate of $1 \mathrm{~mm} / \mathrm{min}$ until failure. At the top on each side of the GFRP-RC beams, directly underneath the position of the load cell, two strain gauges were attached to measure concrete strain. Also, one strain gauge was attached to each of the tensile GFRP reinforcement bars at the center to measure the average tensile strain. All data including load, midspan deflection and strain were recorded with a high-speed data acquisition system (NI PXIe-1078). Fig. 3 shows the test setup of the GFRP-RC beams under static loading.

\subsection{Impact Testing}

Six GFRP-RC beams were subjected to a $580 \mathrm{~kg}$ high capacity free falling drop hammer as shown in Fig. 4 . The test setup involved fixing two steel blocks to the floor so that the GFRP-RC beams had a clear span of $2000 \mathrm{~mm}$ with a 200 mm overhang on each side. All impact GFRP-RC beams were simply supported and positioned on a steel pin and a steel roller. To prevent rebound during impact, steel frame rollers were connected to the steel blocks. The drop hammer was lifted mechanically to the required drop height using an automotive control system. The drop hammer was released using an electronic quick release system. The dynamic midspan deflections were determined by image processing technique using high-speed video camera recordings by positioning a leveler next to the midspan of the beams. Black and white dots were marked onto the beams in order to accurately analyze the deflections. The recording rate of the high-speed video camera was 1000 frames/sec. The dynamic concrete strain was not measured due to the extensive damage in the impact area caused by the drop hammer. However, the dynamic tensile strain was measured from the strain gauges located in the middle of the GFRP tensile reinforcement bars. The recording rate of the high-

172 speed camera was 1000 frames per second. The high-speed data acquisition system, NI-PXI-1050, was used to record 173 all the data, including impact force (load cell connected to the underside of the drop hammer) and dynamic tensile strain, with a frequency of 100,000 samples per second.

\section{4. Experimental Results and Discussions}

\section{$177 \quad 4.1$ Response under Static Loading}

$178 \quad$ 4.1.1 Failure Modes

179 The GFRP-RC beams were designed to have two distinct failure modes under static loading: GFRP reinforcement 180 rupture (for beams with $\rho_{f}=0.5 \%$ ) and concrete crushing (for beams with $\rho_{f}=1.0 \%$ and $2.0 \%$ ). During testing, 
the beams designed as under-reinforced (GFRP-RC beams 80-\#2S-0.5-S and 120-\#2S-0.5-S) showed vertical flexural cracking, which initially formed around the midspan. Flexural cracks started to form at around $3 \mathrm{kN}$. New vertical cracks started to propagate closer to the supports at higher loading levels. Already formed cracks around the midspan continued to propagate vertically. The GFRP-RC beams failed because of the rupture of GFRP reinforcement bars (Fig. 5). This occurred unexpectedly with no sign of warning. Concrete strain at the time of failure was measured as 0.002 and 0.0017 for GFRP-RC beams 80-\#2S-0.5-S and 120-\#2S-0.5-S, respectively (Fig. 6). Rupture strain of GFRP reinforcement bars was not recorded, since the strain gauges failed prior to failure of the GFRP-RC beams. At the time of failure, the experimental load-carrying capacities were measured as $15 \mathrm{kN}$ and $16.2 \mathrm{kN}$ for beams 80-\#2S-0.5$\mathrm{S}$ and 120-\#2S-0.5-S, respectively. Midspan deflections, $\Delta_{\text {exp }}$, were recorded as $81.8 \mathrm{~mm}$ and $77.5 \mathrm{~mm}$ for beams 80 \#2S-0.5-S and 120-\#2S-0.5-S, respectively.

For the over-reinforced GFRP-RC beams (beams 80-\#3HM-1.0-S, 80-\#4HM-2.0-S, 120-\#3HM-1.0-S, and 120\#4HM-2.0-S), two distinct failure modes were observed. Initially, the crushing of concrete cover occurred. This occurred at compressive strains between 0.003 and 0.004 (Fig. 6), which is considered "failure" from a design point of view. Thus, at these recorded concrete strains, experimental load carrying capacity $\left(P_{u}\right)$ was determined. Also, at this point, strains in the GFRP reinforcement bars (ranging from 1.3\% to 1.9\%) were lower than the rupture strain, indicating a concrete crushing failure (Fig 6). However, the GFRP-RC beams showed signs of continually sustaining the load, which indicated signs of reserve capacity or an amount of pseudo "ductility". At higher loading levels, concrete cover continued to crush before the total failure. At the total failure, the GFRP-RC beams failed by the rupture of the GFRP reinforcement bars and were unable to carry additional loads (Fig. 7).

\subsubsection{Load-Midspan Deflection Response}

202 The load-midspan deflection response of the GFRP-RC beams under static loading is shown in Fig. 8. All GFRP-RC 203 beams displayed a bi-linear response. Initially, before cracking, the bending stiffness of the beams was high. The 204 bending stiffness reduced once the cracking occurred, especially for the GFRP-RC beams with the lowest amount of reinforcement. This was attributed to the low elastic modulus of the \#2S bars. From the preliminary test, the modulus 206 of elasticity was calculated as 37.5 GPa for the \#2S GFRP reinforcement bars. For higher amounts of reinforcement, 207 the bending stiffness reduced, but not as drastic as for the GFRP-RC beams with $\rho_{f}=0.5 \%$. Energy absorption 
reinforced GFRP-RC beams, at the first major drop in load carrying capacity, which was considered "failure” (at $E_{1}$ ) and thus the reserve capacity or "ductility" was calculated after this loading point, that is $E_{2}$. A similar approach was adopted in Goldston et al. [37] and Goldston et al. [38] to calculate the energy absorption capacity of the beam. The GFRP-RC beams 80-\#2S-0.5-S and 120-\#2S-0.5-S had no reserve capacity as they collapsed because of the rupture of GFRP reinforcement bars. Total energy absorption capacities for the GFRP-RC beams ranged from $714 \mathrm{~J}$ to 6377 J. Table 3 reports the results for the GFRP-RC beams tested under static loading.

\subsubsection{Influence of Concrete Strength and Tensile Reinforcement}

217 The influence of concrete compressive strength and amount of tensile reinforcement were systematically investigated 218 to understand their influences on the behavior of GFRP-RC beams under static loading, in terms of load carrying capacity, midspan deflection, and post-cracking bending stiffness. For the GFRP-RC beams with $\rho_{f}=0.5 \%$, the effect of concrete compressive strength had minimal influence on the load carrying capacity. For the increase in the concrete compressive strength from $95 \mathrm{MPa}$ to $117 \mathrm{MPa}$, the load increased by $8 \%$ (15 kN to $16.2 \mathrm{kN})$. This is because

222 the GFRP-RC beams were designed as under-reinforced beams and hence their failure was governed by the strength 223 of the GFRP reinforcement bars under tension. Midspan deflection was shown to decrease by 5\% (81.8 $\mathrm{mm}$ to 77.5 $\mathrm{mm}$ ) for $\rho_{f}=0.5 \%$ for an increase in the concrete compressive strength (95 MPa to $177 \mathrm{MPa}$ ). A $12 \%$ increase in post-cracking bending stiffness was observed for $\rho_{f}=0.5 \%$ for an increase in the concrete compressive strength from $22695 \mathrm{MPa}$ to $117 \mathrm{MPa}$.

227 Concrete compressive strength was more influential for the GFRP-RC beams with tensile longitudinal reinforcement 228 ratios of $\rho_{f}=1.0 \%$ and $\rho_{f}=2.0 \%$ in increasing the load carrying capacity, as the failure was governed by the 229 compressive strength of concrete (crushing of concrete cover). For $\rho_{f}=1.0 \%$ and $\rho_{f}=2.0 \%$, the load increased by $23027 \%$ (33 kN to $41.8 \mathrm{kN}$ ) and 13\% (46.1 kN to $52.2 \mathrm{kN}$ ), respectively for the increase in the concrete compressive 231 strength from $95 \mathrm{MPa}$ to $117 \mathrm{MPa}$. However, increasing concrete compressive strength increased the midspan 232 deflection by $17 \%$ and $10 \%$ for $\rho_{f}=1.0 \%$ and $\rho_{f}=2.0 \%$, respectively. In terms of post-cracking bending stiffness, 233 for $\rho_{f}=1.0 \%$, the stiffness increased by $10 \%$ for an increase in concrete compressive strength. However, for $\rho_{f}=$ $2342.0 \%$, a reduction of $0.07 \%$ in post-cracking bending stiffness was observed. At higher reinforcement ratios, higher 
compressive strength on load carrying capacity, midspan deflection and post-cracking bending stiffness is shown in Fig. 9, Fig. 10 and Fig. 11, respectively. In terms of reinforcement ratio, the increase in the amount of tensile longitudinal GFRP reinforcement increased the load-carrying capacity, reduced deflection and increased post-cracking bending stiffness, regardless of concrete compressive strength as shown in Fig. 9, Fig. 10 and Fig. 11. For the GFRP-RC beams with concrete compressive strength of $95 \mathrm{MPa}$, the load carrying capacity increased by 120\%, with a decrease in the midspan deflection of 23\% and an increase in post-cracking bending stiffness by $231 \%$ for the increase in the $\rho_{f}$ from $0.5 \%$ to $1.0 \%$. This significantly large change in the post-cracking bending stiffness is due to the change in failure mode (from the rupture of the GFRP reinforcement to the crushing of concrete). However, for the increase in the $\rho_{f}$ from $1.0 \%$ to $2.0 \%$, the load carrying capacity increased by $40 \%$, with $7 \%$ reduction in the deflection and $61 \%$ increase in the post-cracking bending stiffness. Similar results were observed for the UHSC (117 MPa) GFRP-RC beams. For the increase in the reinforcement ratio $\rho_{f}$ from $0.5 \%$ to $1.0 \%$ and from $1.0 \%$ to $2.0 \%$, the load-carrying capacity increased by $158 \%$ and $25 \%$, respectively. A decrease of $5 \%$ in the midspan deflection was observed for a change in the $\rho_{f}$ from $0.5 \%$ to $1.0 \%$, compared to $12 \%$ for the increase in the $\rho_{f}$ from $1.0 \%$ to $2.0 \%$. In terms of post-cracking bending stiffness, an increase of $224 \%$, and $47 \%$ was observed for an increase in the $\rho_{f}$ from $0.5 \%$ to $1.0 \%$ and from $1.0 \%$ to 2.0 , respectively.

\subsubsection{Experimental versus FRP Code Recommendations}

254 The FRP design recommendation [4] for the calculation of nominal load carrying, $P_{n}$, was compared using 255 experimental results for load carrying capacity $\left(P_{u}\right)$ for the GFRP-RC beams under static loading. Based on the 256 preliminary material testing results, nominal bending moment and load carrying capacities were calculated. In general, 257 the ACI [4] provided relatively conservative results compared to the experimental results, with a mean $P_{n} / P_{u}=0.73$

258 (Table 3). That is, the ACI [4] under-predicted load by an average of 37\%. Regardless of the failure mode (concrete 259 crushing or GFRP reinforcement rupture), the experimental load carrying capacity was found to be higher to that of 260 the calculated nominal load carrying capacity for all GFRP-RC beams.

261 The most conservative results were achieved at the highest tensile longitudinal GFRP reinforcement ratio $\left(\rho_{f}=\right.$ $2622.0 \%$ ). For $\rho_{f}=2.0 \%$, an average of $P_{n} / P_{u}=0.70$ (under-prediction by 43\%) was calculated for ACI [4]. For $\rho_{f}=$ $2630.5 \%$, ACI [4] under-predicted deflection by an average of 37\%. The least conservative results were observed for the 
GFRP-RC beams with $\rho_{f}=1.0 \%$. For the GFRP-RC beams with $\rho_{f}=1.0 \%$, the midspan deflection was underpredicted by $28 \%$. In terms of concrete strength, for the higher the concrete strength (117 MPa), more conservative the nominal load carrying capacity was calculated by ACI [4] compared to experimental load carrying capacity.

267 According to ACI [4], for the concrete compressive strength of $117 \mathrm{MPa}$, a mean $P_{n} / P_{u}=0.71$ was calculated (underprediction of $41 \%$ ), compared to $P_{n} / P_{u}=0.76$ for concrete compressive strength of $95 \mathrm{MPa}$ (under-prediction of 32\%). Table 3 reports the comparison between experimental load carrying capacity and nominal load capacity according to ACI [4].

\subsection{Response under Impact Loading}

\section{$273 \quad$ 4.2.1 Failure Modes}

274 Three GFRP-RC beams with the tensile longitudinal GFRP reinforcement ratios of $\rho_{f}=1.0 \%$ and $\rho_{f}=2.0 \%$ were 275 subjected to various drop hammer heights. The quasi-static energy absorption capacity of the beam was used as the input impact energy in Hughes and Al-Dafiry [46]. In this study, the quasi-static energy absorption capacity of the

277 beams was used to select the initial drop height. The quasi-static energy absorption capacities of the GFRP-RC beam 278 120-\#3HM-1.0-S, at 50\%, 75\% and, 100\% were $2029 \mathrm{~J}, 3043 \mathrm{~J}$ and $4057 \mathrm{~J}$, respectively. Hence, the three drop heights 279 were calculated as $355 \mathrm{~mm}, 533 \mathrm{~mm}$ and $710 \mathrm{~mm}$, respectively. For GFRP-RC beam 120-\#5HM-2.0-S, at 50\%, 75\%, and 100\% energy absorption capacity, the calculated static energy absorption capacities were $3189 \mathrm{~J}$, $4783 \mathrm{~J}$, and 6377

$281 \mathrm{~J}$, respectively. Hence, the drop heights were calculated as $550 \mathrm{~mm}$, $825 \mathrm{~mm}$, and $1100 \mathrm{~mm}$, respectively. Overall, the 282 experimental failure mode and general behavior including crack patterns were relatively similar for all six GFRP-RC beams subjected to various drop heights. The experimental failure mode was found to shift under impact loading as a

284 result of the use of UHSC. This resulted in localized concrete crushing on the top surface with flexural cracks observed 285 around the impact region, with flexural-shear cracks occurring closer towards the support regions. This can be seen in Fig. 12 which shows the point of impact between the drop hammer and the GFRP-RC beam, displaying flexural-shear

287 cracks. This was expected as the impact area is subjected to high shear forces and large bending moments.

288 The GFRP-RC beam 120-\#3HM-1.0- $\mathrm{I}_{0.355}$ experienced minor crushing of the concrete cover on the top surface at the impact point as shown in Fig. 13(a). During impact, cracks were predominately observed as a combination of flexure,

290 flexure-shear and minor shear cracks propagating from the tensile region throughout the height of the GFRP-RC beam.

291 The majority of these cracks were observed to be localized around the impact zone. A few flexure-shear cracks were 
observed closer towards the supports. When the beam was subjected to impact energy of $2029 \mathrm{~J}$, there was no

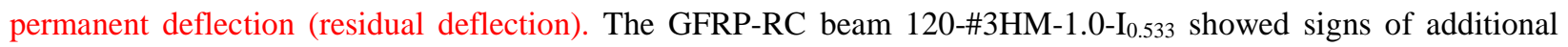

294 crushing of concrete cover, with the exposure of the compressive GFRP reinforcement bars (Fig. 13(b)). The crushing 295 of concrete cover was not symmetric under the impact area, with the localized crushing of concrete cover to one side of the impact point. Under a drop hammer height of $533 \mathrm{~mm}$, a small amount of rupture of the tensile concrete cover occurred and the GFRP tensile reinforcement bars were exposed around the impact zone, which significantly widened a few cracks around the midspan. The cracks were mostly the flexure cracks throughout the span of the GFRP-RC beam. A few flexure-shear cracks and a few minor inclined shear cracks were also observed. The GFRP-RC beam 120-\#3HM-1.0- $\mathrm{I}_{0.710}$ showed extremely localized concrete cover crushing and rupture of the tensile concrete cover, causing the concrete to spall off as shown in Fig. 13 (c). The spalling off of the concrete was symmetrical under the impact point, which exposed the compressive and tensile GFRP reinforcement bars. Also, a predominant flexural crack pattern around the impact zone was observed. Only a few signs of flexure-shear cracks and minor inclined shear cracking were observed. This GFRP-RC beam showed the least number of cracks during impact. By close inspection, some signs of the splitting of fibers from GFRP tensile reinforcement bars were observed.

The GFRP-RC beam 120-\#4HM-2.0-I $\mathrm{I}_{0.550}$ experienced minor concrete crushing in the impact zone and cracks along the span as shown in Fig. 13(d). These cracks were predominately vertical with the presence of a few flexure-shear cracks and a minor inclined shear cracks. After the impact, the GFRP-RC beam remained elastic after the removal of the drop hammer mass. GFRP-RC beam 120-\#4HM-2.0-I $\mathrm{I}_{0.825}$ was subjected to impact energy of $4783 \mathrm{~J}$, from a drop height of $825 \mathrm{~mm}$. A large amount of tensile concrete cover spalled off during impact, causing cracks to widen around

311 the midspan as shown in Fig. 13(e). A few more signs of inclined shear cracking were present, especially closer to the 312 support regions. But the majority of cracks were predominately flexure-shear with the presence of flexural cracks. 313 Finally, the impact energy caused permanent deformation (residual deflection) of GFRP-RC beam 120-\#4HM-2.0$314 \mathrm{I}_{0.825}$ with crushing of concrete on the top surface.

315 The GFRP-RC beam 120-\#4HM-2.0-I $\mathrm{I}_{1.1}$ was subjected to an impact height of $1.1 \mathrm{~m}$. The general behavior of GFRP316 RC beam 120-\#4HM-2.0-I I.1 $_{1.1}$ was similar to the behavior of GFRP-RC beam 120-\#4HM-2.0- $\mathrm{I}_{0.825}$, but additional post 317 impact permanent deformation was noticed as shown in Fig. 13(f). In terms of impact zone damage, concrete crushing on the top surface was localized on one side of the impact point. Rupture of the tensile concrete also occurred only on

319 the same side of the impact point where concrete crushing occurred. Also, by close inspection, the impact caused the 
de-bonding of the sand-coat of the GFRP tensile reinforcement bars around the midspan. In terms of cracking, very few cracks were formed compared to GFRP-RC beams 120-\#4HM-2.0- $\mathrm{I}_{0.550}$ and 120-\#4HM-2.0- $\mathrm{I}_{0.825}$. A combination of flexure and flexure-shear cracks were observed and spaced evenly along the span of GFRP-RC beam 120-\#4HM2.0-I $\mathrm{I}_{1.1}$. Moreover, no sign of rupture or splitting of fibers was detected.

\subsubsection{Dynamic Midspan Deflection Response}

Dynamic midspan deflection time history responses for the GFRP-RC beams under impact loading are shown in Fig.

14. These graphs were drawn by image processing from the high-speed camera. Fig. 14 was modified to initiate the first contact point between the drop hammer and the GFRP-RC beams (i.e., at the coordinates of 0, 0). For GFRP-RC beam 120-\#3HM-1.0-I $\mathrm{I}_{0.710}$, a black dot was used to track midspan deflections frame by frame. However, during impact, the crushing of concrete cover caused the black dot to disappear after a period of time. Thus, maximum dynamic midspan deflection $\left(\Delta_{\text {exp }}\right)$ was difficult to be captured and was illustrated by the irregular dynamic midspan deflection time history response. $170 \mathrm{~mm}$ for maximum dynamic midspan deflection was assumed. The remaining GFRP-RC beams had a white dot painted on, which increased the visibility and therefore increased the accuracy for determining the maximum dynamic midspan deflection. A parabolic curve was attained for dynamic midspan deflection versus time, with the first portion of the graph (positive dynamic midspan deflection rate) representing the contact between the drop hammer and the GFRP-RC beam up until maximum dynamic-midspan deflection. At post dynamic midspan deflection, the GFRP-RC beams began to rebound and move in the opposite direction (negative dynamic midspan deflection rate) since the impact energy wasn't sufficient to cause total failure. It is noted that GFRPRC beam 120-\#4HM-2.0-I $\mathrm{I}_{1.1}$ did not rebound as the impact energy caused total collapse. For the other two GFRP-RC beams with $\rho_{f}=1.0 \%$, maximum dynamic midspan deflections were calculated as $93.4 \mathrm{~mm}$ and $75 \mathrm{~mm}$ for GFRPRC beams 120-\#3HM-1.0- $\mathrm{I}_{0.533}$ and 120-\#3HM-1.0- $\mathrm{I}_{0.355}$, respectively. For the GFRP-RC beams with $\rho_{f}=2.0 \%$, dynamic midspan deflection was calculated as $70.5 \mathrm{~mm}, 129.5 \mathrm{~mm}$ and $249.5 \mathrm{~mm}$ for GFRP-RC beams 120-\#4HM2.0- $\mathrm{I}_{0.550}, 120-\# 4 \mathrm{HM}-2.0-\mathrm{I}_{0.825}$ and 120-\#4HM-2.0- $\mathrm{I}_{1.1}$, respectively.

\subsubsection{Dynamic Load-Time History Response}

346 The dynamic load-time history response of the GFRP-RC beams under impact loading in a 120-millisecond window 347 is shown in Fig. 15. Initially, a short high magnitude duration pulse (between $217 \mathrm{kN}$ to $591 \mathrm{kN}$ for all six GFRP-RC 
beams) occurred at the first contact between the GFRP-RC beams and the drop hammer. This is indicative that the dynamic force was initially resisted by the inertia forces at the first contact point. After this short time duration, the dynamic force was then resisted by the GFRP-RC beams flexural resistance for four of the six GFRP-RC beams. Thus, dynamic bending resistance was extracted from the dynamic load-time history response. For GFRP-RC beams 120\#3HM-1.0- $\mathrm{I}_{0.355}, 120-\# 3 H M-1.0-\mathrm{I}_{0.533}, 120-\# 4 H M-2.0-\mathrm{I}_{0.550}$ and 120-\#4HM-2.0- $\mathrm{I}_{0.825}$, dynamic bending resistance was 49.7 kN, 54.4 kN, $66.5 \mathrm{kN}$ and 78.6 kN, respectively. These four GFRP-RC beams displayed well-defined dynamicload time history responses unlike GFRP-RC beams 120-\#3HM-1.0- $\mathrm{I}_{0.710}$ and 120-\#4HM-2.0- $\mathrm{I}_{1.1}$, where the dynamic bending resistance could not be established. The reason for the differences was because for these two GFRP-RC beams, impact energy from the drop hammer caused total collapse, without rebounding, and thus the data wasdistorted. Average dynamic strain $\left(\varepsilon_{\text {frp.avg }}\right)$ is shown in Fig. 16. Initially, prior to the formation of cracking, dynamic strain rate was relatively high. At the start of cracking, a small drop in dynamic strain was observed. Post-cracking, dynamic strain rate reduced as a result of the formation of cracks and low elastic modulus of the GFRP reinforcement bars. The post-cracking strain increased fairly linearly up until average maximum dynamic strain (at approximately $t=0.05 \mathrm{~s}$ and $t=0.04 \mathrm{~s}$, for GFRP-RC beams with $\rho_{f}=1.0 \%$ and $\rho_{f}=2.0 \%$, respectively). For GFRP-RC beam 120-\#4HM2.0- $\mathrm{I}_{1.1}$, the strain gauges failed prior to the recording of maximum dynamic strain. Thus, linear regression analysis was carried out by increasing the post-cracking dynamic strain up to approximately $t=0.04 \mathrm{~s}$, as at this time maximum dynamic strain occurred for the other two GFRP-RC beams with $\rho_{f}=2.0 \%$. The regression analysis gave approximately 3.0\% dynamic strain. For the remaining five GFRP-RC beams, average dynamic strain decreased after maximum dynamic strain decreased due to the rebound effect.

\subsubsection{Influence of Impact Energy}

369 The effect of increasing impact energy on dynamic midspan deflection of the GFRP-RC beams under impact loading 370 is shown in Figure 17. For $\rho_{f}=1.0 \%$, impact energies of $2029 \mathrm{~J}, 3043 \mathrm{~J}$ and $4057 \mathrm{~J}$ were applied to the three GFRP-

371 RC beams. For the GFRP-RC beams with $\rho_{f}=2.0 \%$, impact energies of $3189 \mathrm{~J}, 4783 \mathrm{~J}$ and $6377 \mathrm{~J}$ were applied to 372 the three GFRP-RC beams. For both $\rho_{f}=1.0 \%$ and $\rho_{f}=2.0 \%$, increasing impact energy increased dynamic 373 midspan deflection. For $\rho_{f}=1.0 \%$, increasing impact energy by 50\% (2029 J to $3043 \mathrm{~J}$ ), 100\% (2029 J to $4057 \mathrm{~J}$ ) and 33\% (3043 J to $4057 \mathrm{~J}$ ), dynamic midspan deflection increased by 25\%, 126\% and 82\%, respectively. A significant 375 increase in the dynamic midspan deflection was observed for higher levels of impact energy. This was also evident 

respectively.

379 The effect of increasing impact energy on the maximum dynamic strain of the GFRP-RC beams under impact loading is shown in Fig. 18. For $\rho_{f}=1.0 \%$, increasing impact energy showed to have a linearly increasing effect on the maximum dynamic strain. Increasing the impact energy by $50 \%, 100 \%$ and $33 \%$, the maximum dynamic strain increased by $15 \%, 30 \%$ and $13 \%$, respectively. At $100 \%$ impact energy, the maximum dynamic strain recorded was 2.6\%, which was $22 \%$ lower than the mean rupture strain (3.18\%) obtained from the preliminary testing. However, as noted previously, the rupture of the GFRP reinforcement bars was not evident after impact, only small signs of the splitting of fibers was evident. This illustrates that the GFRP-RC beam could sustain higher levels of impact before total rupture of the GFRP reinforcement bars. For $\rho_{f}=2.0 \%$, increasing impact energy by $50 \%, 100 \%$ and $33 \%$ increased the maximum dynamic strain considerably more, as compared to $\rho_{f}=1.0 \%$, by $18 \%, 76 \%$ and $50 \%$, respectively. At $100 \%$ impact energy, the maximum dynamic strain was approximated to be $3 \%$ through regression analysis, which was $10 \%$ lower than from preliminary material testing (3.30\%). This is illustrated by no signs of splitting or rupture of GFRP reinforcement fibers, since the GFRP reinforcement bars did not reach rupture strain.

\subsubsection{Comparative Analysis of Failure Modes under Static and Impact Loading}

Experimental investigations have shown that failure modes under static and impact loading are quite distinct. The

394 failure mode of the GFRP-RC beams matches with the observation provided by Saatci and Vecchio [12]. Saatci and 395 Vecchio [12] showed that a flexure-critical RC beam subjected to impact loading would experience shear cracking forming a shear "plug" around the impact zone. Comparing the differences in deflections under static and impact

397 loading would not provide any reasonable outcomes due to the significant differences in the overall behavior and 398 failure mode. Thus, failure modes and behavior including crack patterns were compared in terms of midspan deflection 399 under static and impact loading.

400 For GFRP-RC beams 120-\#3HM-1.0-S and 120-\#4HM-2.0-S, at an energy absorption capacity of 50\%, midspan 401 deflections were measured as $82 \mathrm{~mm}$ and $89 \mathrm{~mm}$, respectively. At this midspan deflection, the overall behavior of the 402 GFRP-RC beams displayed signs of crushing of concrete cover with predominately flexural cracks and a few flexural 403 shear-cracks propagating from the tensile region throughout the span of the beam. This type of behavior was also 
observed for the identical GFRP-RC beams under impact loading subjected to drop hammer heights of $355 \mathrm{~mm}$ (GFRP-RC beam 120-\#3HM-1.0- $\mathrm{I}_{0.355}$ ) and $550 \mathrm{~mm}$ (GFRP-RC beam 120-\#4HM-2.0-I $\mathrm{I}_{0.550}$ ). The minor crushing of concrete cover with flexural and flexural-shear cracks forming from the tensile area was observed. At these drop hammer heights, midspan deflections were measured as $75 \mathrm{~mm}$ and $73 \mathrm{~mm}$, for GFRP-RC beams 120-\#3HM-1.0-I $\mathrm{I}_{0.355}$ and 120-\#4HM-2.0-I ${ }_{0.550}$, respectively. At 50\% energy absorption capacities, the failure modes of the GFRP-RC beams were similar regardless of static or impact loading, resulting in relatively similar midspan deflections.

At higher energy absorption capacities, it was observed that failure modes and crack propagation had similar and distinctive differences under static and impact loadings. For GFRP-RC beam 120-\#3HM-1.0-S, at 75\% energy absorption capacity, the overall failure was predominately flexural critical with flexural-shear cracks and crushing of concrete cover on both sides of the loading cell. Also, similar behavior was observed for GFRP-RC beam 120-\#3HM1.0-I $\mathrm{I}_{0.533}$, with the main differences being more localized concrete crushing around the impact zone and rupture of the tensile concrete cover which resulted in the exposure of the tensile GFRP reinforcement bars. Overall, behavior was noticed to be alike and due to the similarities in failure modes, measured deflections were similar. For GFRP-RC beam 120-\#3HM-1.0-S, at 75\% energy absorption capacity, midspan deflection was measured as $106 \mathrm{~mm}$, compared to 93 mm under impact loading for GFRP-RC beam 120-\#3HM-1.0-I.533. However, failure modes for GFRP-RC beam 120\#4HM-2.0-S, at 75\% energy absorption capacity and GFRP-RC beam 120-\#4HM-2.0-I $\mathrm{I}_{0.825}$ were very different. GFRPRC beam 120-\#4HM-2.0-S at 75\% energy absorption capacity exhibited a flexural failure with concrete crushing on the top surface. The GFRP-RC beam 120-\#4HM-2.0- $\mathrm{I}_{0.825}$ experienced localized crushing of the concrete cover, exposing the compressive GFRP reinforcement bars. Furthermore, rupture of tensile concrete cover occurred, causing cracks to widen, with the addition of minor inclined shear cracking around the impact zone. None of this behavior was observed for GFRP-RC beam 120-\#4HM-2.0-S, at 75\% energy absorption capacity, except for the concrete crushing of the cover. As a result of the differences in failure modes, the failure mode developed by GFRP-RC beam 120\#4HM-2.0-I ${ }_{0.825}$ displayed a higher midspan deflection, $139 \mathrm{~mm}$, compared to $116 \mathrm{~mm}$ for GFRP-RC beam 120\#4HM-2.0-S at 75\% energy absorption capacity.

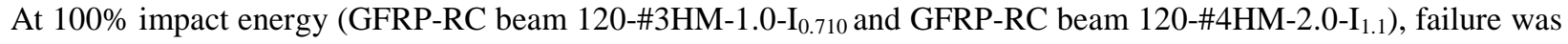
described as a flexural failure. Localized damage around the impact zone, with severe rupture of the tensile concrete cover and crushing of compressive concrete cover, was observed. Very few cracks developed along the span of the beam, with these cracks predominately inclined shear cracks around the impact zone. Permanent deformation was also 
432 evident after the removal of the drop hammer. This caused the GFRP-RC beams to have dynamic midspan deflections of $175 \mathrm{~mm}$ for GFRP-RC beam 120-\#3HM-1.0-I $\mathrm{I}_{0.710}$ and $250 \mathrm{~mm}$ for GFRP-RC beam 120-\#4HM-2.0-I.1. Under static

434 loading, at 100\% energy absorption capacity, flexural cracks and flexural-shear cracks were evident along the span of 435 the GFRP-RC beams, with the crushing of compressive concrete cover and rupture of tensile concrete cover. This type of failure mode resulted in midspan deflections of $128 \mathrm{~mm}$ and $140 \mathrm{~mm}$ for GFRP-RC beams 120-\#3HM-1.0-S and

437 120-\#4HM-2.0-S, respectively. Fig. 19 compares the crack pattern for the GFRP-RC beam with $\rho_{f}=1.0 \%$ at 438 different energy absorption capacities under static loading and impact loading. Fig. 20 compares the crack pattern for the GFRP-RC beam with $\rho_{f}=2.0 \%$ at different energy absorption capacities under static and impact loading.

\subsubsection{Dynamic Amplification Factor (DAF)}

442 A Dynamic Amplification Factor (DAF) was obtained for the GFRP-RC beams. The DAF is defined as the ratio of 443 the experimental dynamic moment capacity $\left(M_{d}\right)$ to the experimental static moment capacity $\left(M_{\text {static }}\right)$. Dynamic 444 moment capacity was calculated using Equation (1). The $R_{1}(t)$ was assumed as half the impact force, that is $R_{1}(t)=$ $445 I(t) / 2$. Thus simplifying Equation (1), $M_{d}=I(t) / 2$, where $L=2000 \mathrm{~mm}$. Static moment capacities $\left(M_{\text {static }}\right)$ were 446 calculated based on energy absorption capacity. That is for GFRP-RC beam 120-\#3HM-1.0-S, at 50\%, 75\%, and 100\% 447 energy absorption capacity, static moment capacities were calculated as 21 kN.m, 23 kN.m and 23 kN.m, respectively. For GFRP-RC beam 120-\#4HM-2.0-S, at 50\%, 75\%, and 100\% energy absorption capacity, static moment capacities

449 were measured as $30 \mathrm{kN} . \mathrm{m}, 32 \mathrm{kN} . \mathrm{m}$ and $35 \mathrm{kN} . \mathrm{m}$, respectively. Table 4 reports the dynamic and static moment 450 capacities of the GFRP-RC beams. Overall, an average DAF was calculated as 1.17 . An average of $17 \%$ higher 451 capacities under dynamic loading was obtained, indicating higher reserve capacity for the GFRP-RC beams under 452 impact loading as compared to static testing. However, a DAF could not be obtained for GFRP-RC beams 120-\#3HM$4531.0-\mathrm{I}_{0.710}$ and 120-\#4HM-2.0-I $\mathrm{I}_{1.1}$ since they totally collapsed, and thus dynamic moment capacity was not calculated. 454 A time history of dynamic moment capacity for GFRP-RC beam 120-\#4HM-2.0-I $\mathrm{I}_{0.825}$ is shown in Fig. 21.

$$
M_{d}(t)=\frac{2 L}{6} R_{1}(t)+\frac{I(t)}{2} \times \frac{L}{6}
$$


457 The design code ACI [4] provides equations to calculate the nominal shear strength of a GFRP-RC beams. The nominal shear strength of a GFRP-RC beams is the sum of the contribution of concrete and the contribution of the

459 steel stirrups to the shear strength. The nominal shear strength values of the beams tested under impact loading were

460 presented in Table 5. To calculate the maximum experimental shear forces, the equilibrium of dynamic forces was used [12]. According to Saatci and Vecchio [12], during the first few milliseconds of impact, the inertia load and

462 impact load of the RC beam coincide. Since the accelerations were not measured in the experiments, the inertia load

463 was assumed to be equal to the impact load during the first 3 milliseconds of impact, when the maximum impact load takes place. The maximum experimental shear force was then calculated and presented in Table 5. It can be observed

465 that when the nominal shear strength of the beam was larger than the experimental maximum shear force, the failure 466 of the beam was flexural failure. However, when the experimental shear force was very close to the shear capacity of 467 the beam, the failure was flexural-shear failure. Therefore, the high shear capacity of the GFRP-RC beams with UHSC 468 prevented the dominant shear failure in the beams.

\section{5. Conclusions}

470 An experimental program consisting of twelve simply supported GFRP bar reinforced concrete beams (GFRP-RC

471 beams) subjected to static and impact loadings has been carried out. The behavior of GFRP-RC beams with varying 472 reinforcement ratio and concrete strengths (HSC and UHSC) have been investigated. The following conclusions have 473 been drawn based on the observations from the experimental results.

474 The failure mode of GFRP-RC beams under static loading (three-point bending) can be determined using sectional 475 analysis used for beams reinforced with steel reinforcement bar. For the GFRP-RC beams with more than balanced 476 reinforcement (over-reinforced), failure was caused by the crushing of concrete cover. For the GFRP-RC beams with 477 less than balanced reinforcement ratio (under-reinforced), failure was observed to be caused by GFRP reinforcement 478 rupture.

479 Load-midspan deflection behavior of GFRP-RC beams under static loading (three-point bending) showed a bi-linear 480 response. The first part of the bi-linear response represented an uncracked section and the second part represented a crack section with a reduction in the bending stiffness. The over-reinforced GFRP-RC beams displayed signs of pseudo "ductility", where the beams were able to resist load before total collapse. The under-reinforced GFRP-RC

483 beams which failed suddenly by rupture of GFRP reinforcement, resulting in no reserve capacity. The design 
recommendation for concrete beams reinforced with FRP bars [24] was found to be very conservative, underpredicting the load carrying capacity by an average of 37\% for the GFRP-RC beams under static loading.

486 The effect of HSC and UHSC was found to influence the overall behavior of GFRP-RC beams under static loading 487 (three-point bending) in terms of load carrying capacity, deflection, and post-cracking bending stiffness. For the GFRP-RC beams with the tensile longitudinal reinforcement ratio of $0.5 \%\left(\rho_{f}=0.5 \%\right)$, the increase in the concrete strength from $95 \mathrm{MPa}$ to $117 \mathrm{MPa}$, the load carrying capacity increased by $8 \%$ (15 kN to $16.2 \mathrm{kN}$ ). The small increase in load carrying capacity is because these GFRP-RC beams are designed as under-reinforced and hence the failure is governed by the tensile strength of the GFRP bars. For GFRP-RC beams with $\rho_{f}=1.0 \%$ and $\rho_{f}=2.0 \%$, load carrying capacity increased by $27 \%(33 \mathrm{kN}$ to $41.8 \mathrm{kN}$ ) and $13 \%$ (46.1 kN to $52.2 \mathrm{kN})$, respectively, for the increase in the concrete compressive strength from $95 \mathrm{MPa}$ to $117 \mathrm{MPa}$. However, increasing concrete strength increased 494 midspan deflection for the GFRP-RC beams with $\rho_{f}=1.0 \%$ and $\rho_{f}=2.0 \%$ by $17 \%$ and $10 \%$, respectively. In terms 495 of post-cracking bending stiffness, for the GFRP-RC beams with $\rho_{f}=1.0 \%$, stiffness increased $10 \%$ for a change in 496 concrete strength from HSC (95 MPa) to UHSC (117 MPa). At higher reinforcement ratios $\left(\rho_{f}=2.0 \%\right)$, concrete 497 strength (HSC and UHSC) did not improve the post-cracking bending stiffness.

498 Under impact loading, the UHSC GFRP-RC beams displayed a change in failure, from shear to a flexural failure. This was a result of using Ultra High Strength Concrete (UHSC) as opposed to Normal Strength Concrete (NSC) or HSC. Flexural cracking around the impact region with the crushing of concrete cover was observed. Flexural-shear cracks were observed closer to the supports. However, the GFRP-RC beams under static loading failed in a flexural response.

502 Thus, the shear behavior of flexure-critical GFRP-RC beams must be considered when designing structures subjected 503 to impact loads.

504 The increase in impact energy increased the dynamic midspan deflection of the GFRP-RC beams. At lower levels of 505 impact energy, for the same amount of reinforcement dynamic deflections were found to be similar. However, at very 506 large levels of impact energy, a significant increase in the dynamic deflection was observed. Also, by increasing 507 impact energy by 50\%, 33\% and 100\%, the dynamic strain in the GFRP reinforcement bars increased approximately 508 linearly, especially for a reinforcement ratio of $\rho_{f}=1.0 \%$. The average dynamic amplification factor was 1.17. 
The authors express special thanks to the technical officers at the High Bay Laboratories of the University of Wollongong, Australia. The first author thanks the University of Wollongong for the financial support for his $\mathrm{PhD}$ study.

\section{References}

[1] Kamal M, Safaan M, Al-Gazzar M. Ductility of concrete beams reinforced with hybrid FRP rebars. HBRC J, Hous \& Build Res Cent. 2006;2:1-12.

[2] Saleh Z, Sheikh MN, Remennikov AM, Basu A. Numerical investigations on the flexural behavior of GFRP-RC beams under monotonic loads. Structures. 2019;20:255-67.

[3] Saleh Z, Goldston M, Remennikov AM, Sheikh MN. Flexural design of GFRP bar reinforced concrete beams: An appraisal of code recommendations. Journal of Building Engineering. 2019:100794.

[4] ACI. Guide for the Design and Construction of Structural Concrete Reinforced with Fiber-Reinforced Polymer (FRP) Bars (ACI 440.1R-15). Farmington Hills, MI 48331: American Concrete Institute; 2015.

[5] Dancygier AN. Effect of reinforcement ratio on the resistance of reinforced concrete to hard projectile impact. Nuclear Engineering and Design. 1997;172:233-45.

[6] Fujikake K, Li B, Soeun S. Impact Response of Reinforced Concrete Beam and Its Analytical Evaluation. Journal of Structural Engineering. 2009;135:938-50.

[7] Hughes G, Beeby A. Investigation of the effect of impact loading on concrete beams. STRUCTURAL ENGINEER-PART B. 1982;60:45-52.

[8] Kishi N, Mikami H, Matsuoka KG, Ando T. Impact behavior of shear-failure-type RC beams without shear rebar. International Journal of Impact Engineering. 2002;27:955-68.

[9] Kishi N, Nakano O, Matsuoka K, Ando T. Experimental study on ultimate strength of flexural-failure-type RC beams under impact loading. 2001.

[10] May IM, Chin YM. Reinforced concrete beams under drop-weight impact loads. Comput Concr. 2009;3:79-90. [11] Ohnuma H, Ito C, Nomachi S. Dynamic response and local rupture of reinforced concrete beam and slab under impact loading. 1985.

[12] Saatci S, Vecchio FJ. Effects of Shear Mechanisms on Impact Behavior of Reinforced Concrete Beams. ACI Structural Journal. 2009;106:78-86.

[13] Adhikary SD, Li B, Fujikake K. Low Velocity Impact Response of Reinforced Concrete Beams: Experimental and Numerical Investigation. Int J Prot Struct. 2015;6:81-111.

[14] Adhikary SD, Li B, Fujikake K. Residual resistance of impact-damaged reinforced concrete beams. Mag Concr Res. 2015;67:364-78.

[15] Adhikary SD, Li B, Fujikake K. State-of-the-art review on low-velocity impact response of reinforced concrete beams. Mag Concr Res. 2016;68:701-23.

[16] Min KH, Kwon KY, Lee JY, Yoon YS. Effects of steel fibre and shear reinforcement on static and impact load resistances of concrete beams. Mag Concr Res. 2014;66:998-1006.

[17] Yoo D-Y, Banthia N, Kim S-W, Yoon Y-S. Response of ultra-high-performance fiber-reinforced concrete beams with continuous steel reinforcement subjected to low-velocity impact loading. Compos Struct. 2015;126:23345.

[18] Zhan T, Wang Z, Ning J. Failure behaviors of reinforced concrete beams subjected to high impact loading. Eng Fail Anal. 2015;56:233-43.

[19] Zhao DB, Yi WJ, Kunnath SK. Shear Mechanisms in Reinforced Concrete Beams under Impact Loading. Journal of Structural Engineering. 2017;143:04017089.

[20] Pham TM, Hao H. Plastic hinges and inertia forces in RC beams under impact loads. International Journal of Impact Engineering. 2017;103:1-11. 
[21] Pham TM, Hao H. Effect of the plastic hinge and boundary conditions on the impact behavior of reinforced concrete beams. International Journal of Impact Engineering. 2017;102:74-85.

[22] Ho D. Impact response of reinforced concrete: An experimental and numerical investigation. 2000.

[23] May I, Chen Y, Roger D, Owen J, Feng Y, Bere A. Behaviour of reinforced concrete beams and slabs under dropweight impact loads. 6th Asia-Pacific Conference on Shock and Impact Loads on Structures, Perth, W Australia2005. p. 375-82.

[24] Miyamoto A, King MW, Fujii M. Analysis of failure modes for reinforced concrete slabs under impulsive loads. Structural Journal. 1991;88:538-45.

[25] Zhang M, Shim V, Lu G, Chew C. Resistance of high-strength concrete to projectile impact. International Journal of Impact Engineering. 2005;31:825-41.

[26] Ågårdh L, Magnusson J, Hansson H. High strength concrete beams subjected to impact loading-An experimental study. FOA Defence Research Establishment Report. 1999.

[27] Kalpana VG, Subramanian K. Behavior of concrete beams reinforced with GFRP BARS. Journal of Reinforced Plastics and Composites. 2011;30:1915-22.

[28] Faza S, GangaRao H. Glass FRP reinforcing bars for concrete. Fiber reinforced (FRP) reinforcement for concrete structures: properties and applications In: Developments in civil engineering. 1993;42:167-88.

[29] Nanni A. Flexural behavior and design of RC members using FRP reinforcement. Journal of structural engineering. 1993;119:3344-59.

[30] Yost JR, Gross SP. Flexural design methodology for concrete beams reinforced with fiber-reinforced polymers. Structural Journal. 2002;99:308-16.

[31] Idris Y, Ozbakkaloglu T. Flexural behavior of FRP-HSC-steel composite beams. Thin-Walled Struct. 2014;80:207-16.

[32] Cladera A, Mari A. Experimental study on high-strength concrete beams failing in shear. Engineering Structures. 2005;27:1519-27.

[33] El-Sayed AK, El-Salakawy EF, Benmokrane B. Shear capacity of high-strength concrete beams reinforced with FRP bars. ACI Structural Journal. 2006;103:383.

[34] Johnson MK, Ramirez JA. Minimum shear reinforcement in beams with higher strength concrete. Structural Journal. 1989;86:376-82.

[35] Pendyala RS, Mendis P. Experimental study on shear strength of high-strength concrete beams. Structural Journal. 2000;97:564-71.

[36] Yoon YS, Cook WD, Mitchell D. Minimum shear reinforcement in normal, medium, and high-strength concrete beams. ACI Structural journal. 1996;93:576-84.

[37] Goldston M, Remennikov A, Sheikh MN. Experimental investigation of the behaviour of concrete beams reinforced with GFRP bars under static and impact loading. Engineering Structures. 2016;113:220-32.

[38] Goldston MW, Remennikov A, Sheikh MN. Flexural behaviour of GFRP reinforced high strength and ultra high strength concrete beams. Construction and Building Materials. 2017;131:606-17.

[39] Vincent T, Ozbakkaloglu T. Influence of concrete strength and confinement method on axial compressive behavior of FRP confined high-and ultra high-strength concrete. Composites Part B: Engineering. 2013;50:413-28. [40] Ozbakkaloglu T. Behavior of square and rectangular ultra high-strength concrete-filled FRP tubes under axial compression. Composites Part B: Engineering. 2013;54:97-111.

[41] Australia S. Methods of Testing Concrete - Compressive Strength Tests - Concrete, Mortar and Grout Specimens. AS10129. Sydney, New South Wales, Australia: Standards Australia; 2014.

[42] ASTM. Standard Test Method for Tensile Properties of Fiber Reinforced Polymer Matrix Composite Bars. D7205/ D7205M. West Conshohocken (PA): American Society for Testing and Materials; 2011.

[43] ASTM. Standard Testing Methods and Definitions for Mechanical Testing of Steel Products. A370-14. West Conshohocken (PA): American Society for Testing and Materials; 2014.

[44] Adhikary SD, Li B, Fujikake K. Dynamic behavior of reinforced concrete beams under varying rates of concentrated loading. International Journal of Impact Engineering. 2012;47:24-38.

[45] Adhikary SD, Li B, Fujikake K. Residual resistance of impact-damaged reinforced concrete beams. 2014.

[46] Hughes B, AI-Dafiry H. Impact energy absorption at contact zone and supports of reinforced plain and fibrous concrete beams. Construction and Building Materials. 1995;9:239-44. 


\section{Tables}

Table 1. Concrete Mix Designs of NSC and UHSC

\begin{tabular}{|c|c|c|}
\hline \multirow{2}{*}{ Material } & \multicolumn{2}{|c|}{ Nominal Concrete Strength } \\
\cline { 2 - 3 } & $80 \mathrm{MPa}$ & $120 \mathrm{MPa}$ \\
\hline Bastion General Purpose Cement & $540 \mathrm{~kg} / \mathrm{m}^{3}$ & $600 \mathrm{~kg} / \mathrm{m}^{3}$ \\
\hline Fine Grade Fly Ash & $40 \mathrm{~kg} / \mathrm{m}^{3}$ & $\mathrm{~N} / \mathrm{A}$ \\
\hline Micro Silica Densified Silica Fume & $40 \mathrm{~kg} / \mathrm{m}^{3}$ & $40 \mathrm{~kg} / \mathrm{m}^{3}$ \\
\hline $10 \mathrm{~mm}$ Aggregate & $1040 \mathrm{~kg} / \mathrm{m}^{3}$ & $1020 \mathrm{~kg} / \mathrm{m}^{3}$ \\
\hline Coarse Sand & $420 \mathrm{~kg} / \mathrm{m}^{3}$ & $450 \mathrm{~kg} / \mathrm{m}^{3}$ \\
\hline Fine Sand & $100 \mathrm{~kg} / \mathrm{m}^{3}$ & $150 \mathrm{~kg} / \mathrm{m}^{3}$ \\
\hline $\begin{array}{c}\text { Sika Viscocrete PC HRF2 } \\
\text { (Superplasticiser) }\end{array}$ & $4 \mathrm{~L} / \mathrm{m}^{3}$ & $5 \mathrm{~L} / \mathrm{m}^{3}$ \\
\hline Water & $160 \mathrm{~L} / \mathrm{m}^{3}$ & $155 \mathrm{~L} / \mathrm{m}^{3}$ \\
\hline
\end{tabular}


Table 2. Details of GFRP-RC Beams

\begin{tabular}{|c|c|c|c|c|c|c|}
\hline \multirow{2}{*}{ GFRP-RC Beam } & \multirow{2}{*}{$\begin{array}{c}d \\
(\mathrm{~mm})\end{array}$} & \multirow{2}{*}{$\begin{array}{c}\rho_{f} \\
(\%)\end{array}$} & \multirow{2}{*}{$\begin{array}{c}f_{c}^{\prime} \\
(\mathrm{MPa})\end{array}$} & \multirow{2}{*}{$\begin{array}{c}\rho_{S} \\
(\%)\end{array}$} & \multirow{2}{*}{$\begin{array}{c}\text { Reinforcement } \\
\text { Condition }\end{array}$} & \multirow{2}{*}{$\frac{M_{n}(\mathrm{kN} . \mathrm{m})}{(\mathrm{ACI}[4])}$} \\
\hline & & & & & & \\
\hline 80-\#2S-0.5-S & 127.8 & 0.5 & 80 & 0.50 & Under & 5.7 \\
\hline 80-\#3HM-1.0-S & 126.2 & 1.0 & 80 & 0.50 & Over & 13.6 \\
\hline 80-\#4HM-2.0-S & 124.7 & 2.0 & 80 & 0.50 & Over & 16.0 \\
\hline 120-\#2S-0.5-S & 127.8 & 0.5 & 120 & 0.50 & Under & 5.7 \\
\hline 120-\#3HM-1.0-S & 126.2 & 1.0 & 120 & 0.50 & Over & 15.2 \\
\hline 120-\#4HM-2.0-S & 124.7 & 2.0 & 120 & 0.50 & Over & 18.0 \\
\hline 120-\#3HM-1.0-I ${ }_{0.71}$ & 126.2 & 1.0 & 120 & 0.50 & Over & 15.3 \\
\hline 120-\#3HM-1.0-I $\mathrm{I}_{0.533}$ & 126.2 & 1.0 & 120 & 0.50 & Over & 15.3 \\
\hline 120-\#3HM-1.0-I $\mathrm{I}_{0.355}$ & 126.2 & 1.0 & 120 & 0.50 & Over & 15.3 \\
\hline 120-\#4HM-2.0-I ${ }_{1.1}$ & 124.7 & 2.0 & 120 & 0.50 & Over & 18.1 \\
\hline 120-\#4HM-2.0- $\mathrm{I}_{0.825}$ & 124.7 & 2.0 & 120 & 0.50 & Over & 18.1 \\
\hline 120-\#4HM-2.0-I $\mathrm{I}_{0.550}$ & 124.7 & 2.0 & 120 & 0.50 & Over & 18.1 \\
\hline
\end{tabular}

Note: $d$ is effective depth, $\rho_{f}$ is tensile reinforcement ratio, $f^{\prime}{ }_{c}$ is nominal concrete compressive strength, $\rho_{s}$ is shear reinforcement ratio and $M_{n}$ is nominal moment capacity calculated according to ACI (2015). 
Table 3. GFRP-RC Beams under Static Loading

\begin{tabular}{|c|c|c|c|c|c|c|c|c|}
\hline \multirow{2}{*}{$\begin{array}{l}\text { GFRP-RC } \\
\text { Beam } \\
\text { (Failure } \\
\text { Mode) }\end{array}$} & \multirow{2}{*}{$\begin{array}{c}\text { Experiment } \\
\text { al Load, } \\
P_{u} \\
(\mathrm{kN})\end{array}$} & \multirow{2}{*}{$\begin{array}{c}\text { Midspan } \\
\text { Deflection } \\
\Delta_{\text {exp }} \\
(\mathrm{mm})\end{array}$} & \multirow[b]{2}{*}{$\begin{array}{c}\text { Reserve } \\
\text { Capacity } \\
E_{2}(\mathrm{~J})\end{array}$} & \multirow{2}{*}{$\begin{array}{c}\text { Total } \\
\text { Energy } \\
\text { Absorption } \\
\left(E_{1}+E_{2}\right) \\
(\mathrm{J})\end{array}$} & \multicolumn{2}{|c|}{ Average Strain } & \multirow{2}{*}{$\begin{array}{l}\text { Nominal } \\
\text { Load, } \\
P_{n}(\mathrm{kN}) \\
\text { ACI [4] }\end{array}$} & \multirow[b]{2}{*}{$P_{n} / P_{u}$} \\
\hline & & & & & $\begin{array}{c}\varepsilon_{f r p . a v g} \\
(\%)\end{array}$ & $\varepsilon_{c . a v g}$ & & \\
\hline $\begin{array}{c}\text { 80-\#2S-0.5-S } \\
\text { (GFRP } \\
\text { Rupture) }\end{array}$ & 15.0 & 81.8 & 0 & 742 & $2.8^{*}$ & 0.002 & 11.4 & 0.76 \\
\hline $\begin{array}{c}\text { 80-\#3HM- } \\
1.0-\mathrm{S} \\
\text { (Concrete } \\
\text { Crushing) }\end{array}$ & 33.0 & 62.6 & 2689 & 3909 & $1.6^{*}$ & $0.003^{*}$ & 27.2 & 0.82 \\
\hline $\begin{array}{l}\text { 80-\#4HM- } \\
\text { 2.0-S } \\
\text { (Concrete } \\
\text { Crushing) }\end{array}$ & 46.1 & 58.3 & 4540 & 6050 & $1.3^{*}$ & $0.0035^{*}$ & 32.0 & 0.70 \\
\hline $\begin{array}{c}\text { 120-\#2S-0.5- } \\
\text { S } \\
\text { (GFRP } \\
\text { Rupture) }\end{array}$ & 16.2 & 77.5 & 0 & 714 & $3.5^{*}$ & 0.0017 & 11.4 & 0.70 \\
\hline $\begin{array}{c}\text { 120-\#3HM- } \\
\text { 1.0-S } \\
\text { (Concrete } \\
\text { Crushing) }\end{array}$ & 41.8 & 73.3 & 2335 & 4057 & $1.9 *$ & $0.004 *$ & 30.4 & 0.73 \\
\hline $\begin{array}{c}\text { 120-\#4HM- } \\
\text { 2.0-S } \\
\text { (Concrete } \\
\text { Crushing) }\end{array}$ & 52.2 & 64.3 & 4494 & 6377 & $1.6^{*}$ & $0.004 *$ & 36 & 0.69 \\
\hline
\end{tabular}

Note:* Data was extrapolated using linear regression analysis to calculate average strain at Peak 1 , $\varepsilon_{\text {frp.avg }}$ is the average strain in the GFRP tensile reinforcement bars and $\varepsilon_{\text {c.avg }}$ is the average strain in the concrete. 
Table 4. Dynamic Amplification Factor (DAF)

\begin{tabular}{|c|c|c|c|}
\hline GFRP-RC Beam & $M_{\text {static }}(\mathrm{kNm})$ & $M_{d}(\mathrm{kNm})$ & DAF \\
\hline 120-\#3HM-1.0-I $\mathrm{I}_{0.355}$ & 21 & 25 & 1.19 \\
\hline 120-\#3HM-1.0-I ${ }_{0.533}$ & 23 & 27 & 1.17 \\
\hline 120-\#3HM-1.0-I $\mathrm{I}_{0.710}$ & 23 & * & $*$ \\
\hline 120-\#4HM-2.0-I ${ }_{0.550}$ & 30 & 33 & 1.10 \\
\hline 120-\#4HM-2.0-I $\mathrm{I}_{0.825}$ & 32 & 39 & 1.22 \\
\hline 120-\#4HM-2.0-I ${ }_{1.1}$ & 35 & $*$ & $*$ \\
\hline \multicolumn{3}{|c|}{ Mean } & 1.17 \\
\hline
\end{tabular}

Note: * DAF could not be calculated since GFRP-RC beams totally collapsed under impact loading and dynamic load-time history response was inconclusive. 
Table 5. Verification of failure modes of the GFRP-RC beams under impact loading

\begin{tabular}{|c|c|c|c|}
\hline GFRP-RC Beam & $\begin{array}{c}\text { Nominal shear } \\
\text { strength } \\
\text { as per ACI [4] } \\
\left(V_{n}\right) \\
(\mathrm{kN})\end{array}$ & $\begin{array}{l}\text { Maximum } \\
\text { experimental } \\
\text { shear force } \\
(\mathrm{kN})\end{array}$ & $\begin{array}{c}\text { Failure } \\
\text { mode }\end{array}$ \\
\hline 120-\#3HM-1.0-I $\mathrm{I}_{0.355}$ & \multirow{3}{*}{51.9} & 27.4 & Flexure \\
\hline 120-\#3HM-1.0-I $\mathrm{I}_{0.533}$ & & 37.6 & Flexure \\
\hline 120-\#3HM-1.0- $\mathrm{I}_{0.710}$ & & 49.2 & Flexure-shear \\
\hline 120-\#4HM-2.0-I $\mathrm{I}_{0.550}$ & \multirow{3}{*}{55.2} & 35.8 & Flexure \\
\hline $120-\# 4 \mathrm{HM}-2.0-\mathrm{I}_{0.825}$ & & 51.2 & Flexure-shear \\
\hline 120-\#4HM-2.0-I $\mathrm{I}_{1.1}$ & & 60.4 & Flexure-shear \\
\hline
\end{tabular}




\section{Figures}

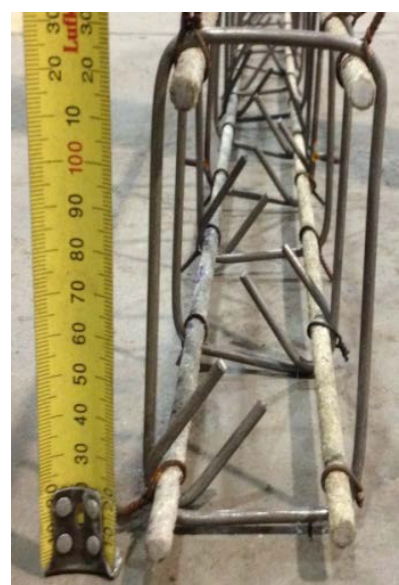

a) $\rho_{f}=0.5 \%$

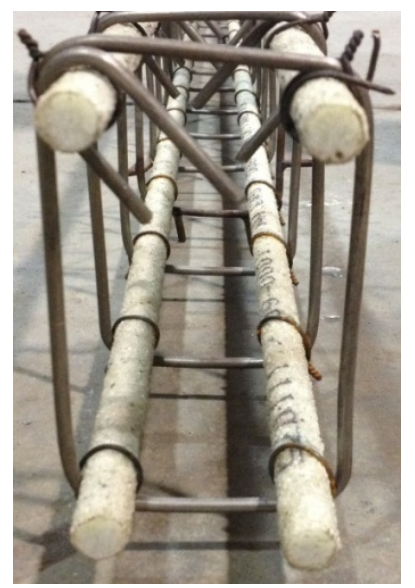

b) $\rho_{f}=1.0 \%$

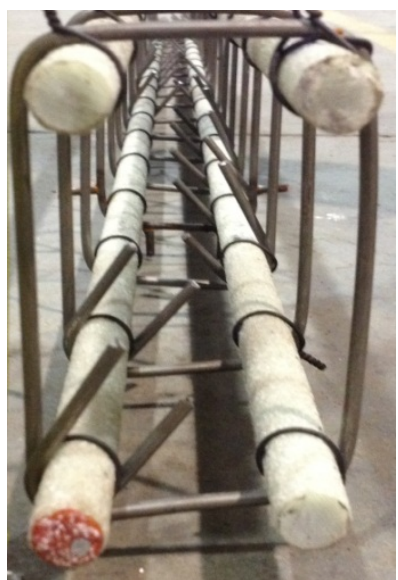

c) $\rho_{f}=2.0 \%$

Figure 1. Reinforcement Cages 


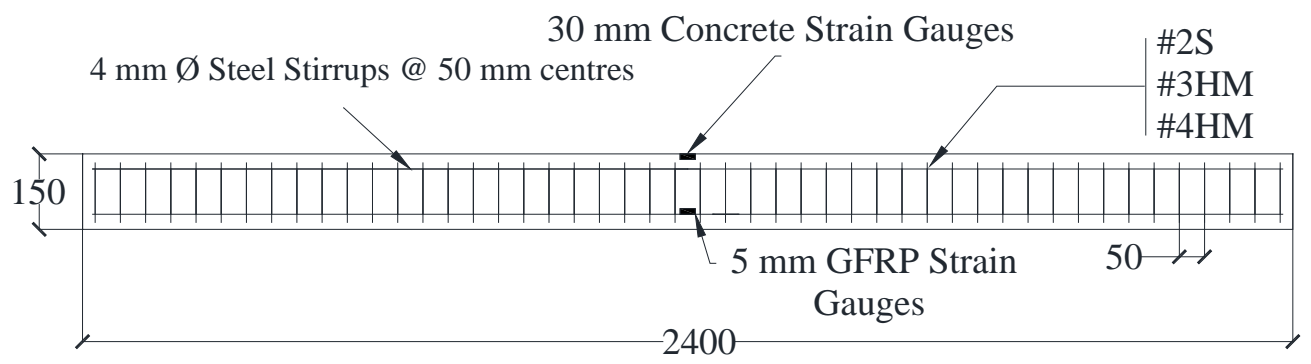

Figure 2. Schematic of a GFRP-RC Beam Specimen 


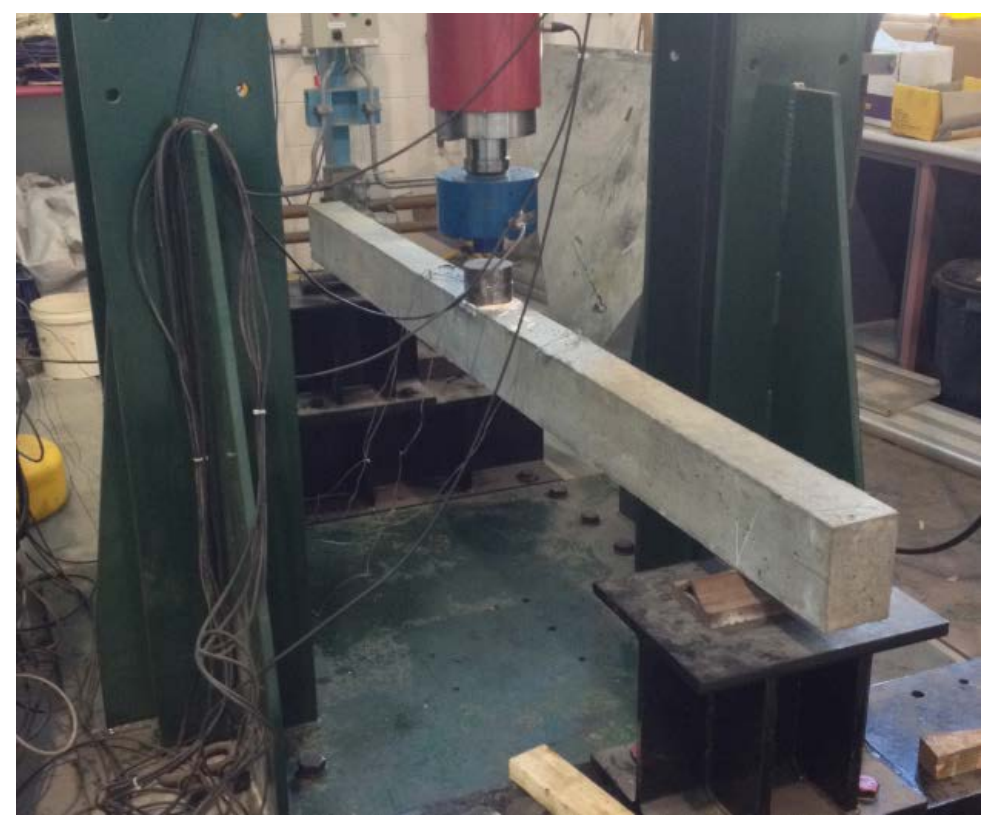

Figure 3. Experimental Set-up for GFRP-RC Beams under Static Loading 


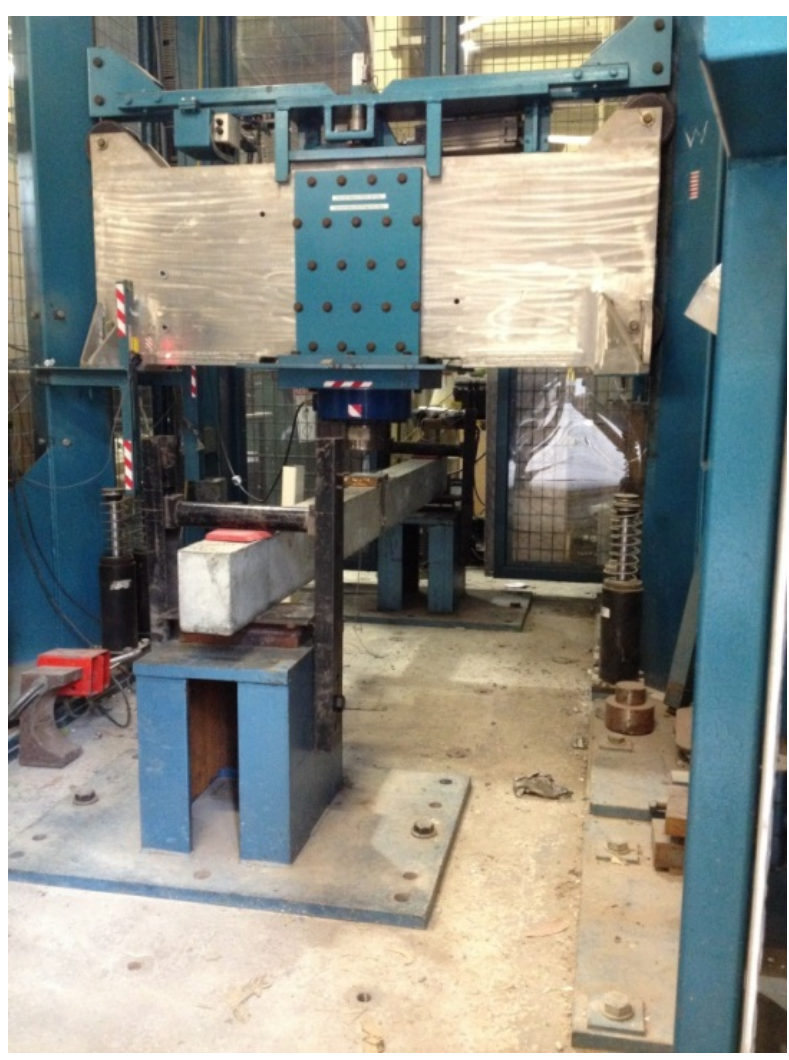

Figure 4. Experimental Set-up for GFRP-RC Beams under Impact Loading 


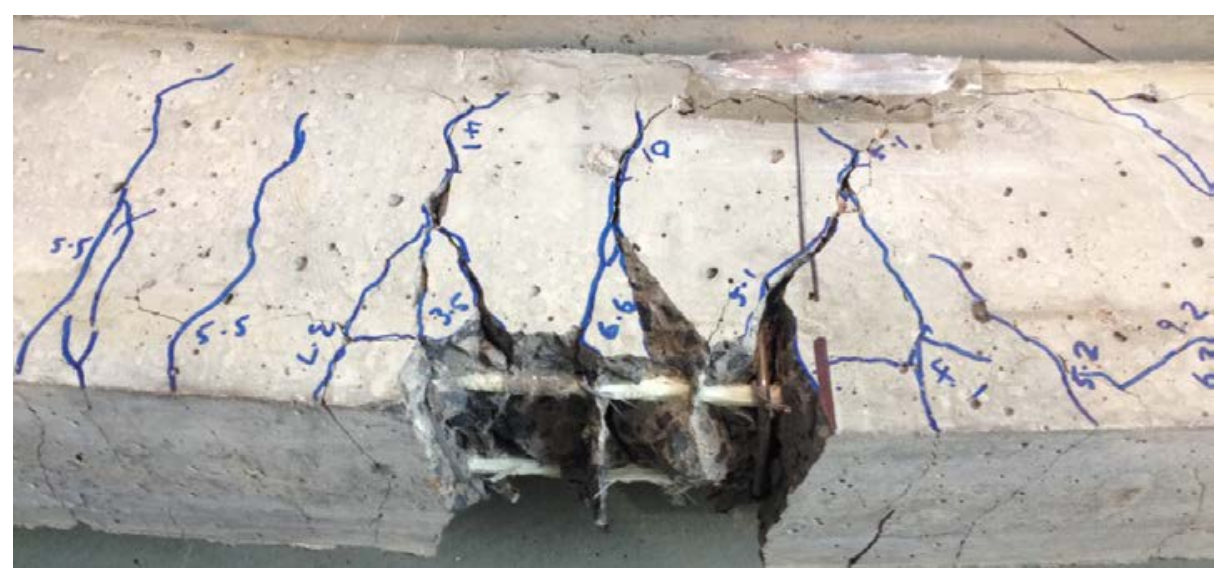

Figure 5. Rupture of GFRP Bar in GFRP-RC Beam 80-\#2S-0.5-S 


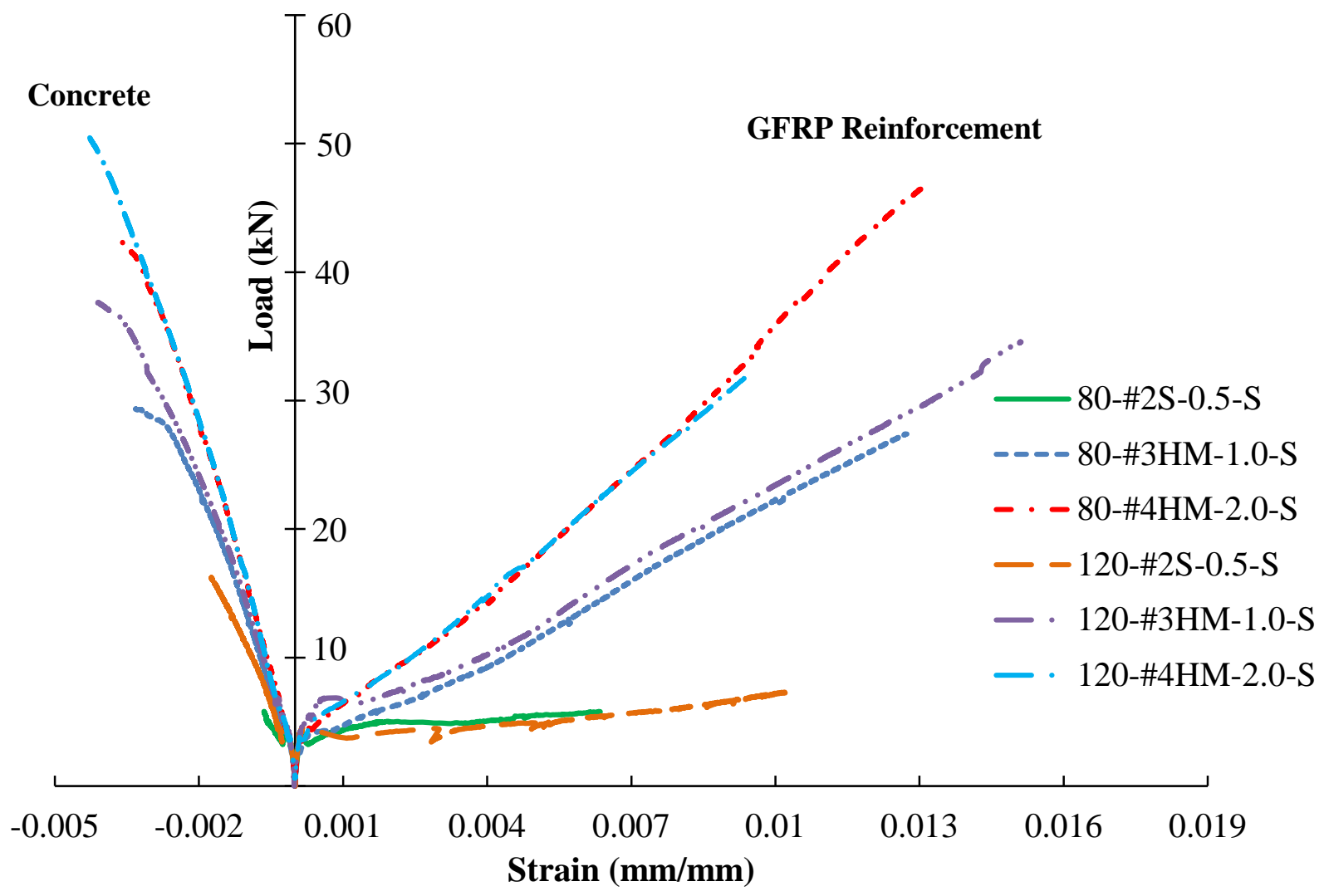

Figure 6. Load-Strain Response of Concrete and GFRP Bar in GFRP-RC Beams under Static Loading 


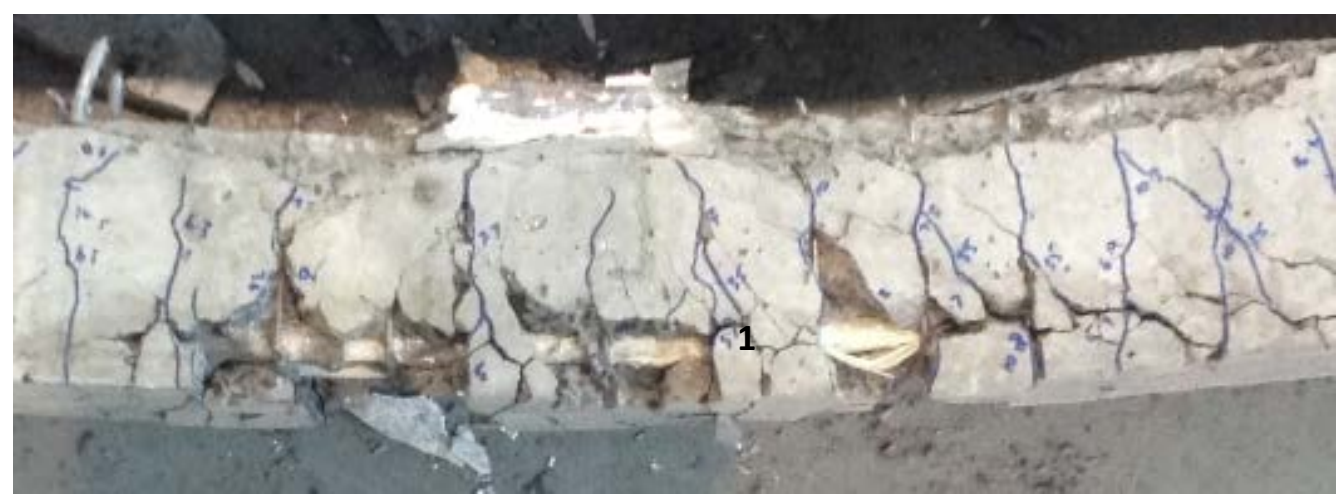

Figure 7. Rupture of GFRP Bars in GFRP-RC Beam 80-\#4HM-2.0-S 


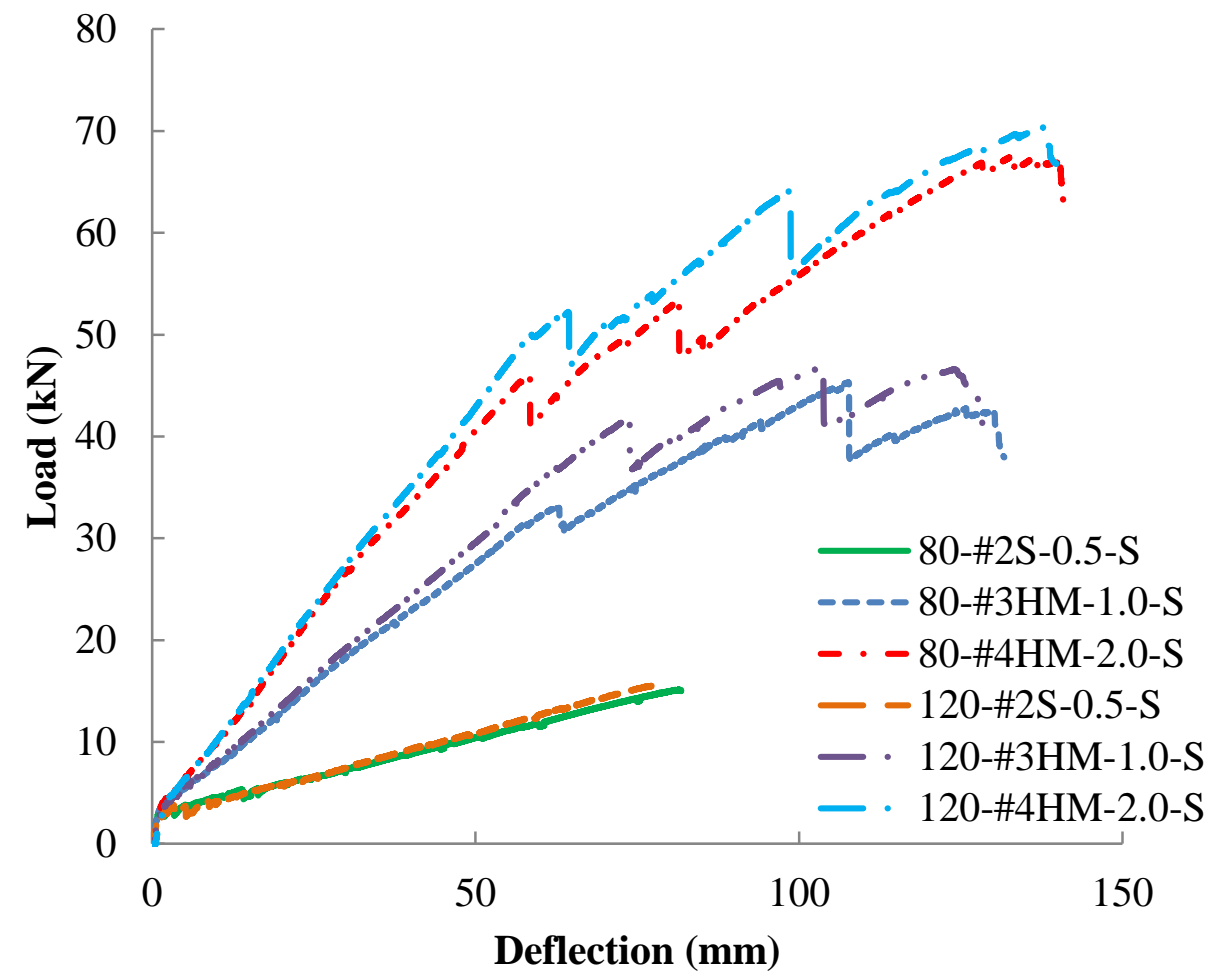

Figure 8. Load-Midspan Deflection Response of GFRP-RC Beams under Static Loading 


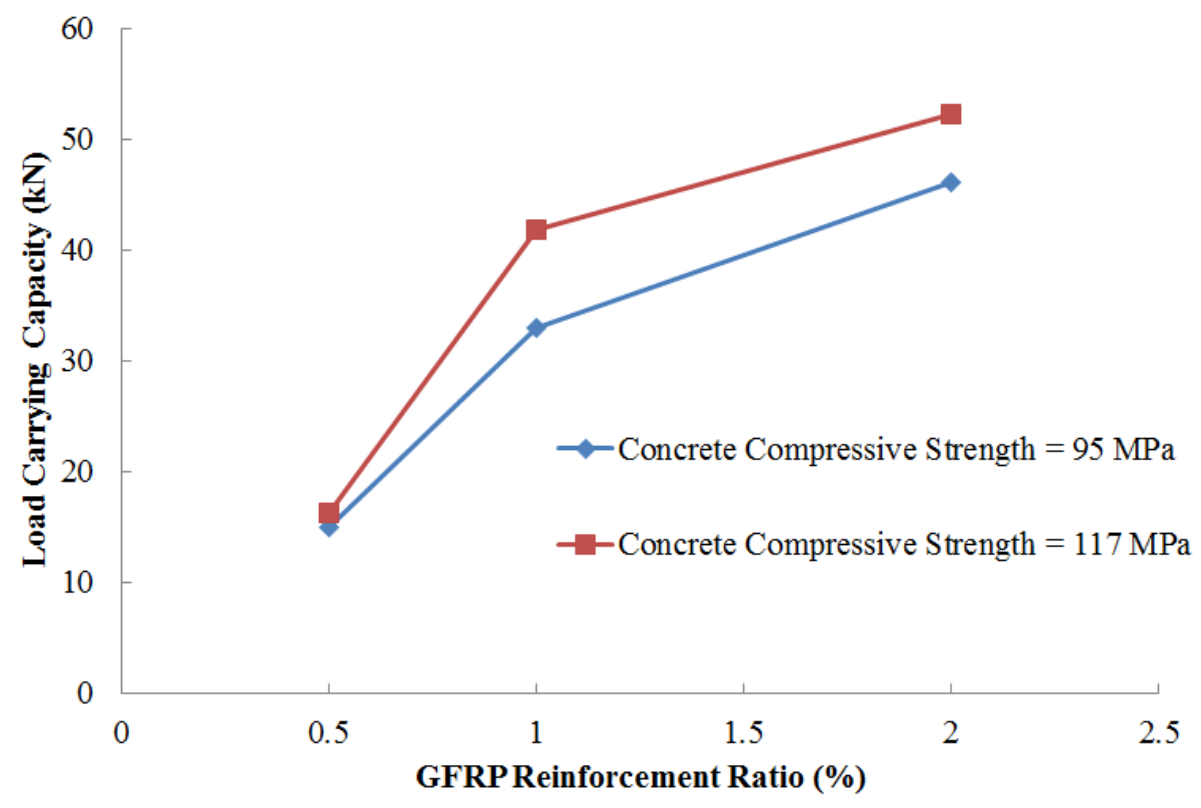

Figure 9. Influence of Concrete Compressive Strength and GFRP Reinforcement Ratio on the Load Carrying Capacity 


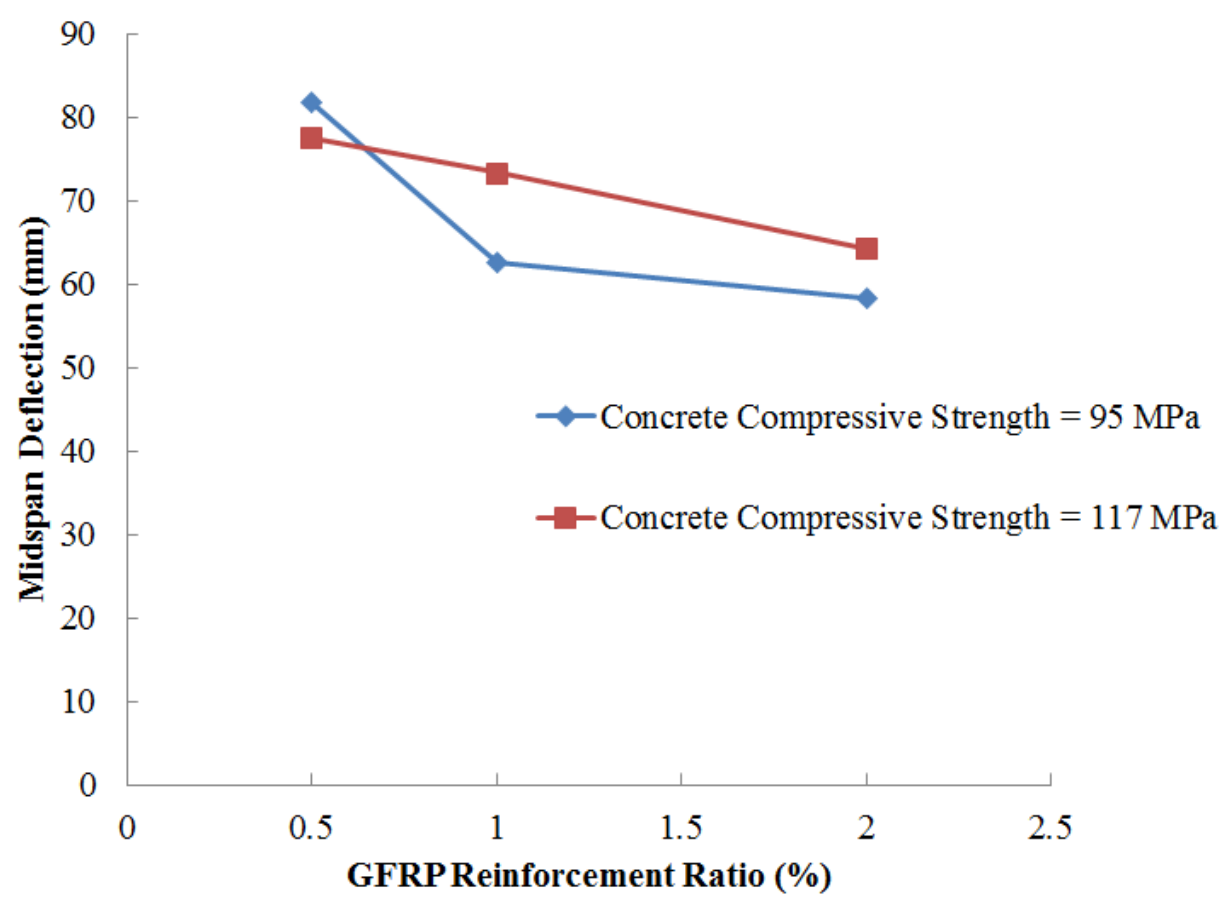

Figure 10. Influence of Concrete Compressive Strength and GFRP Reinforcement Ratio on Midspan Deflection 


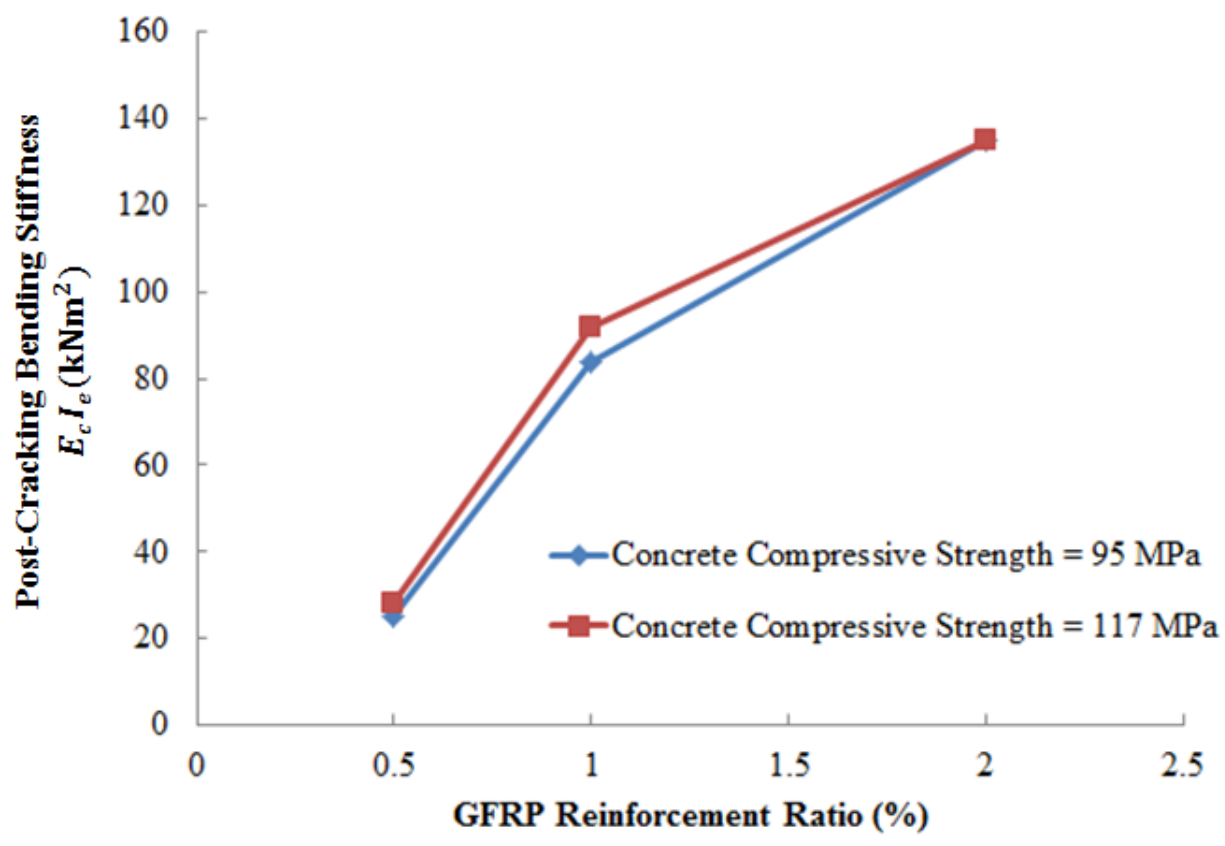

Figure 11. Influence of Concrete Strength and GFRP Reinforcement Ratio on Post-Cracking Bending Stiffness 


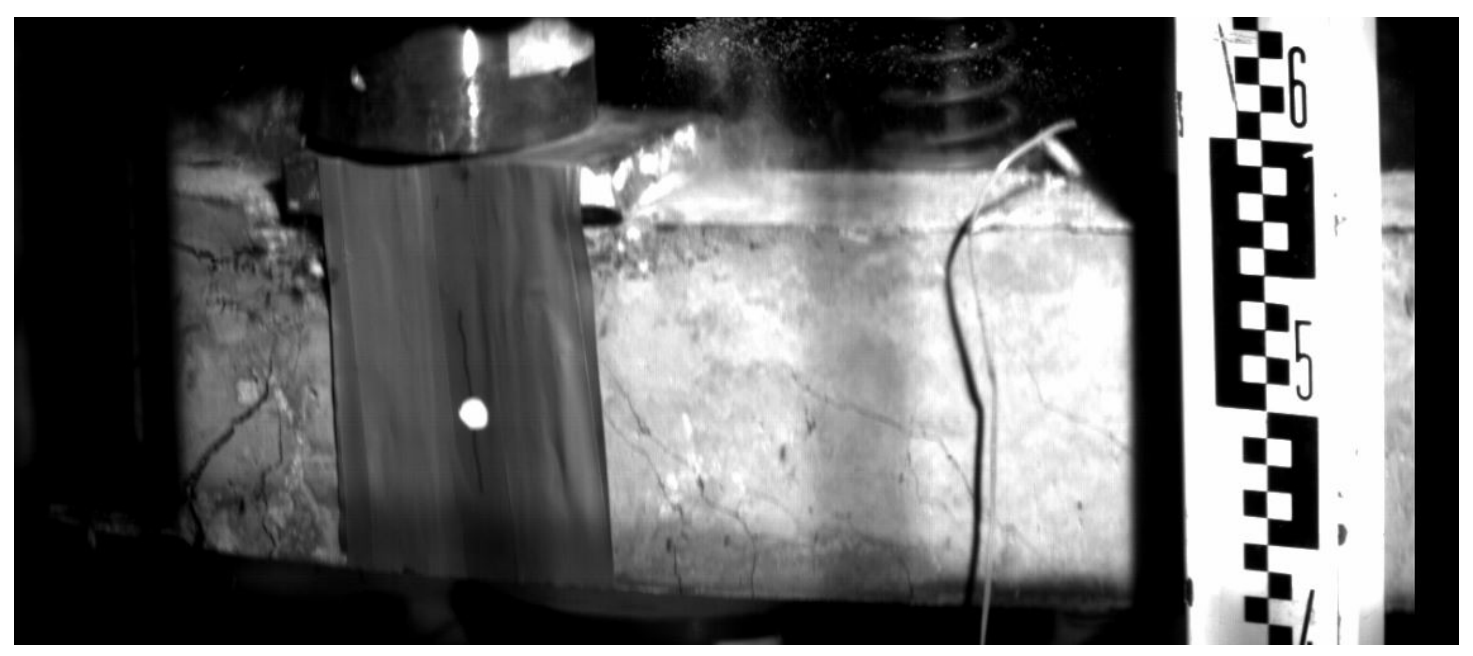

Figure 12. High-Speed Camera showing Formation of Cracks at the point of Contact between the GFRP RC beam and Drop Hammer. 


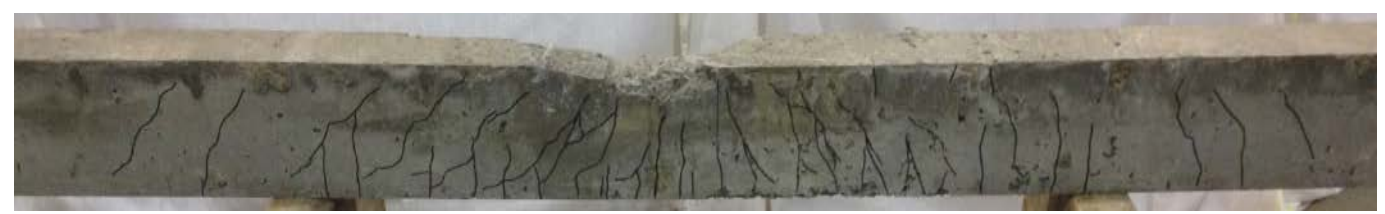

(a)

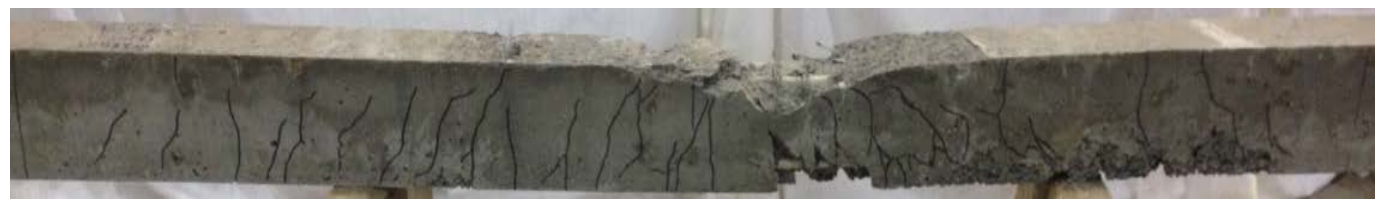

(b)

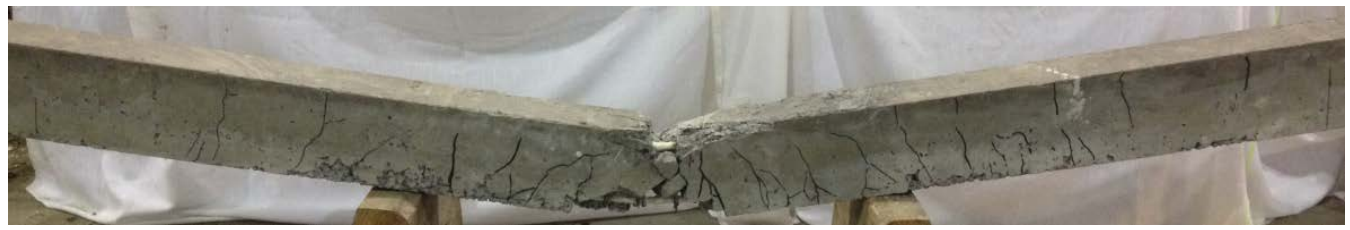

(c)

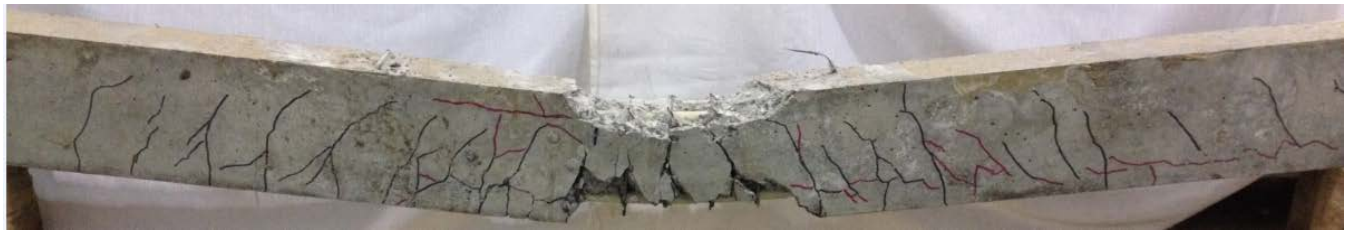

(d)

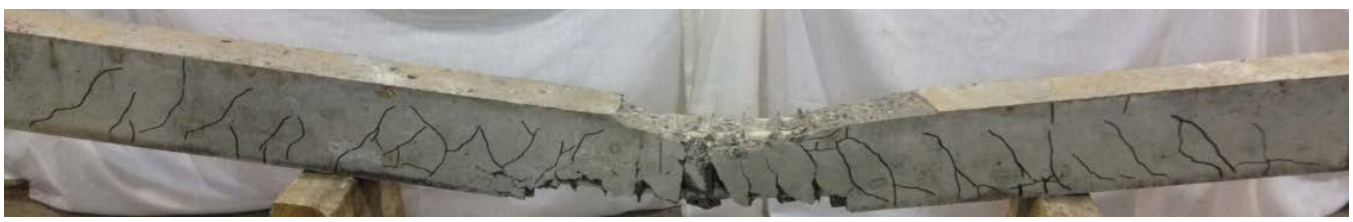

(e)

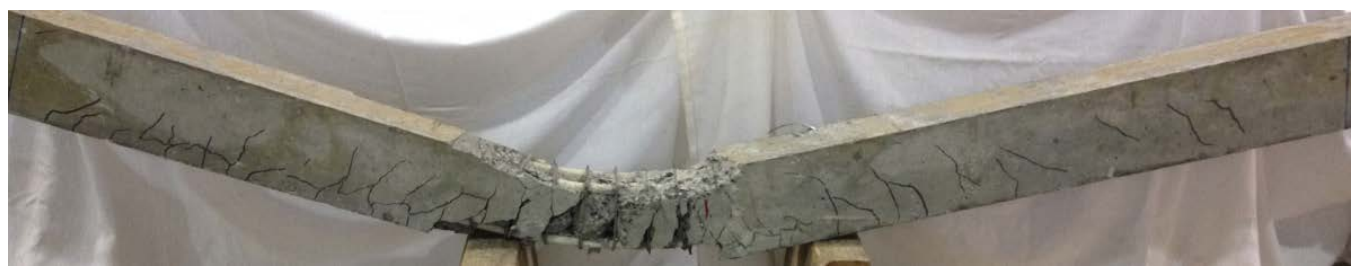

(f)

Figure 13. Failure Modes and Crack Propagation in UHSC GFRP-RC Beams: (a) 120-\#3HM-1.0-I $\mathrm{I}_{0.355}$, (b) 120-

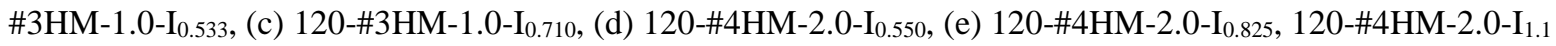




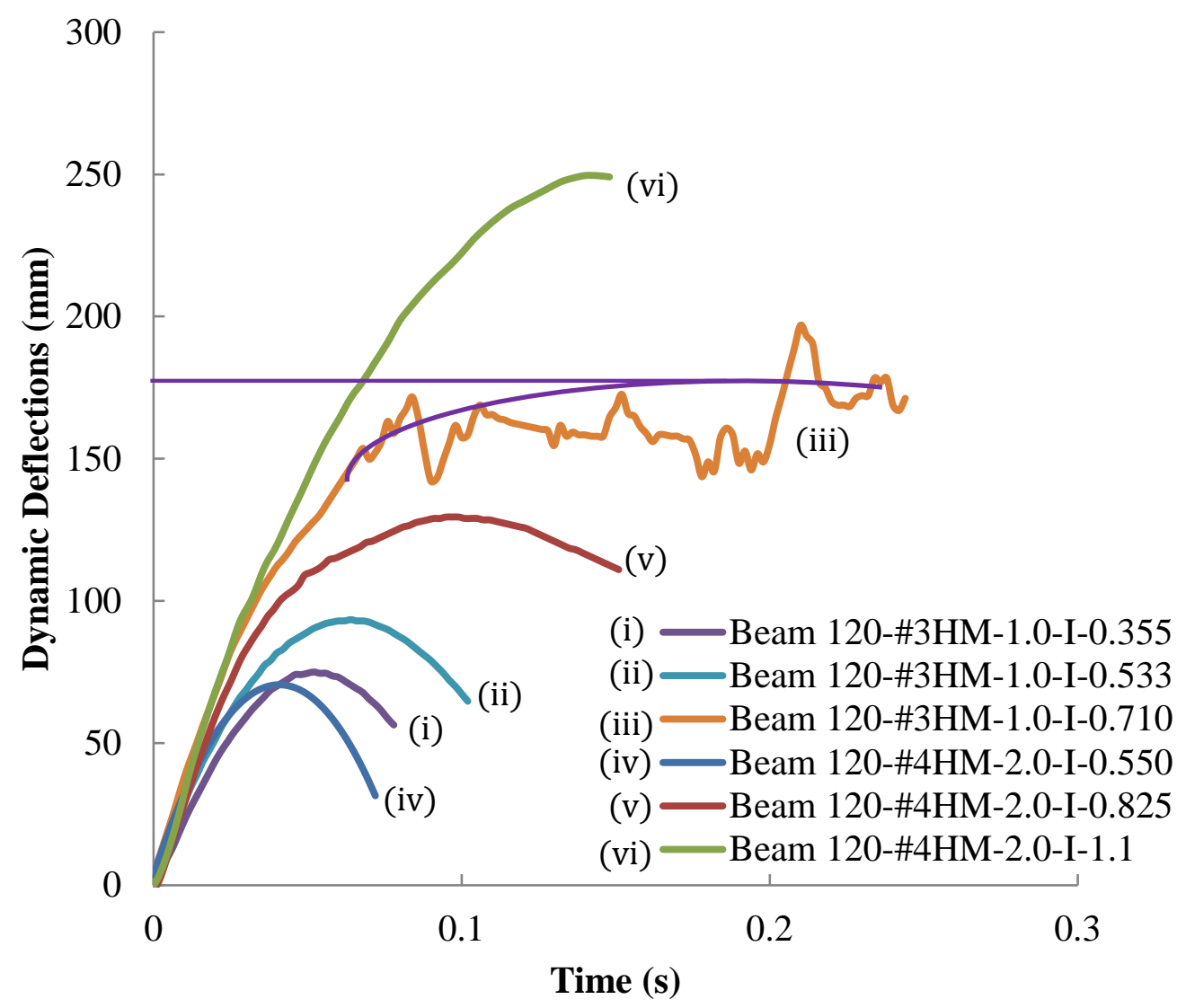

Figure 14. Dynamic Midspan Deflection-Time Histories 


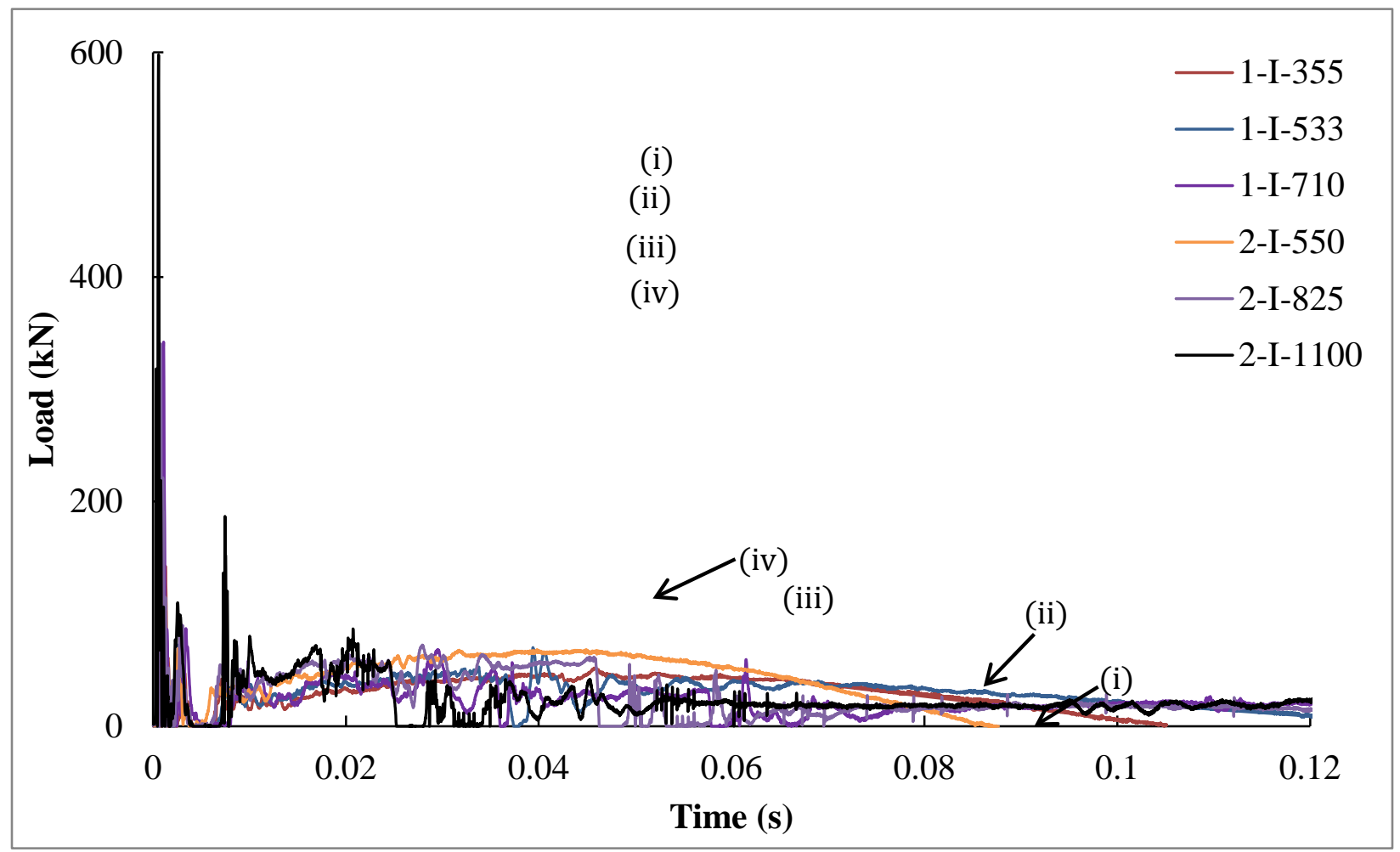

Figure 15. Dynamic Force History Response of GFRP-RC Beams 


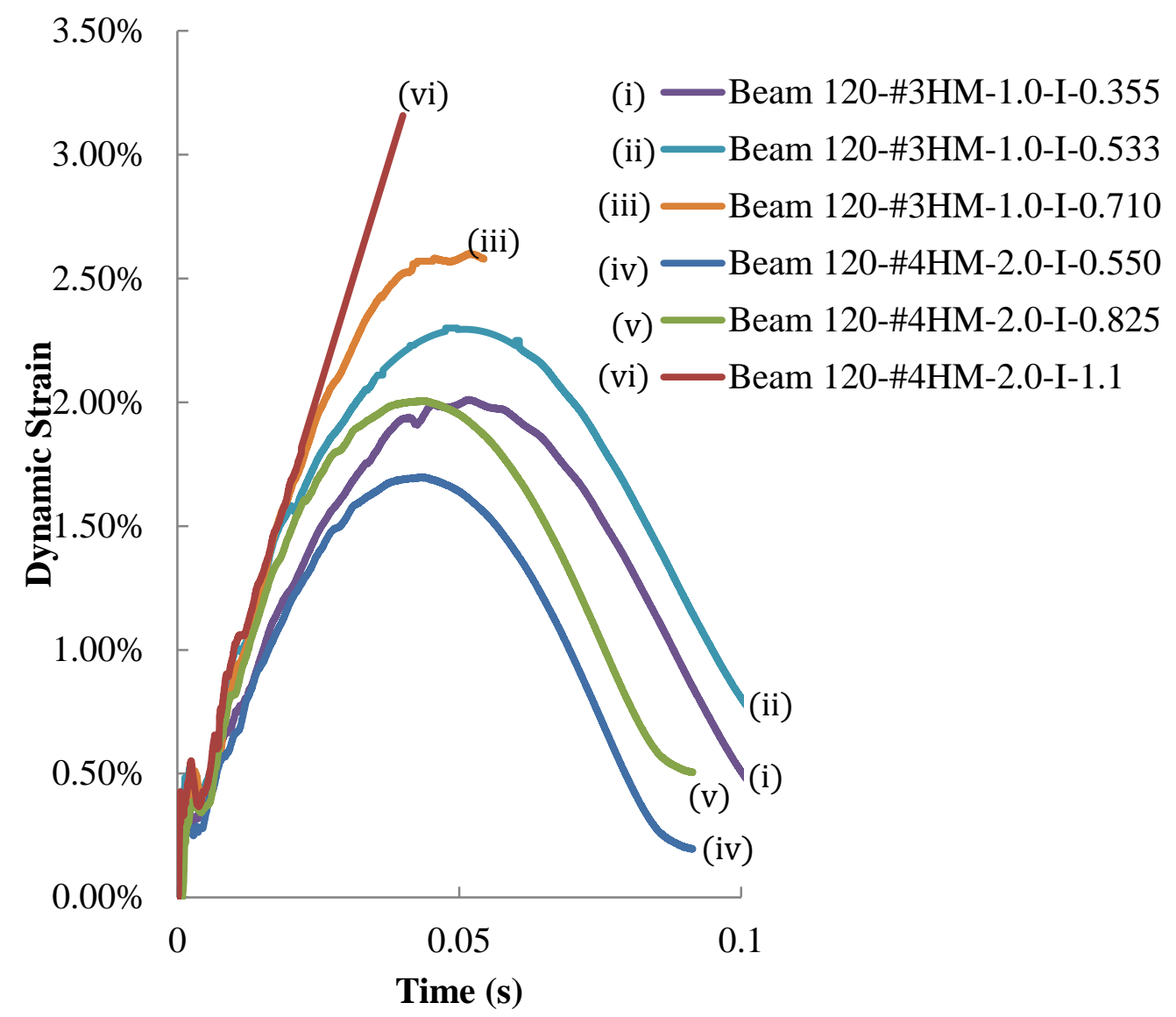

Figure 16. Maximum Dynamic Strain-Time History Response of GFRP-RC Beams 


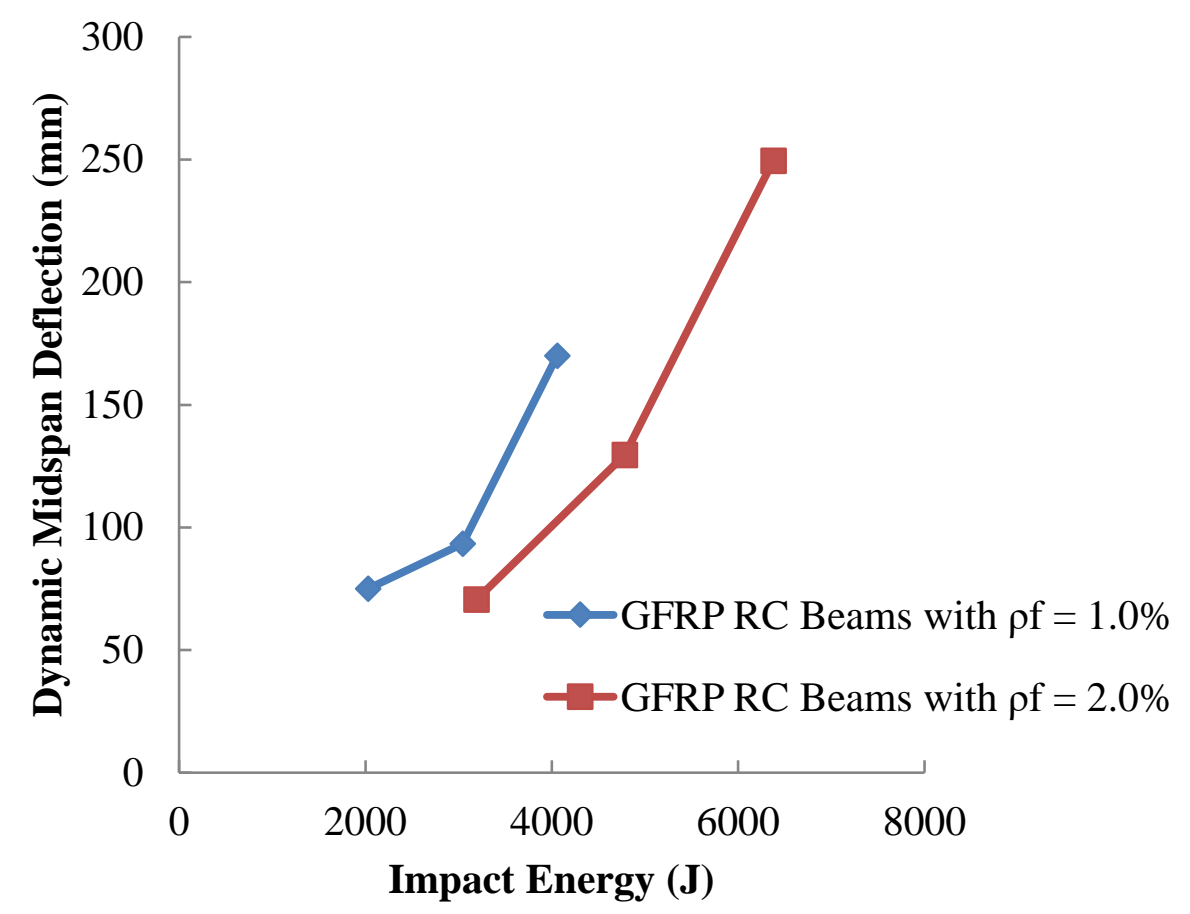

Figure 17. Effect of Impact Energy on Dynamic Midspan Deflection 


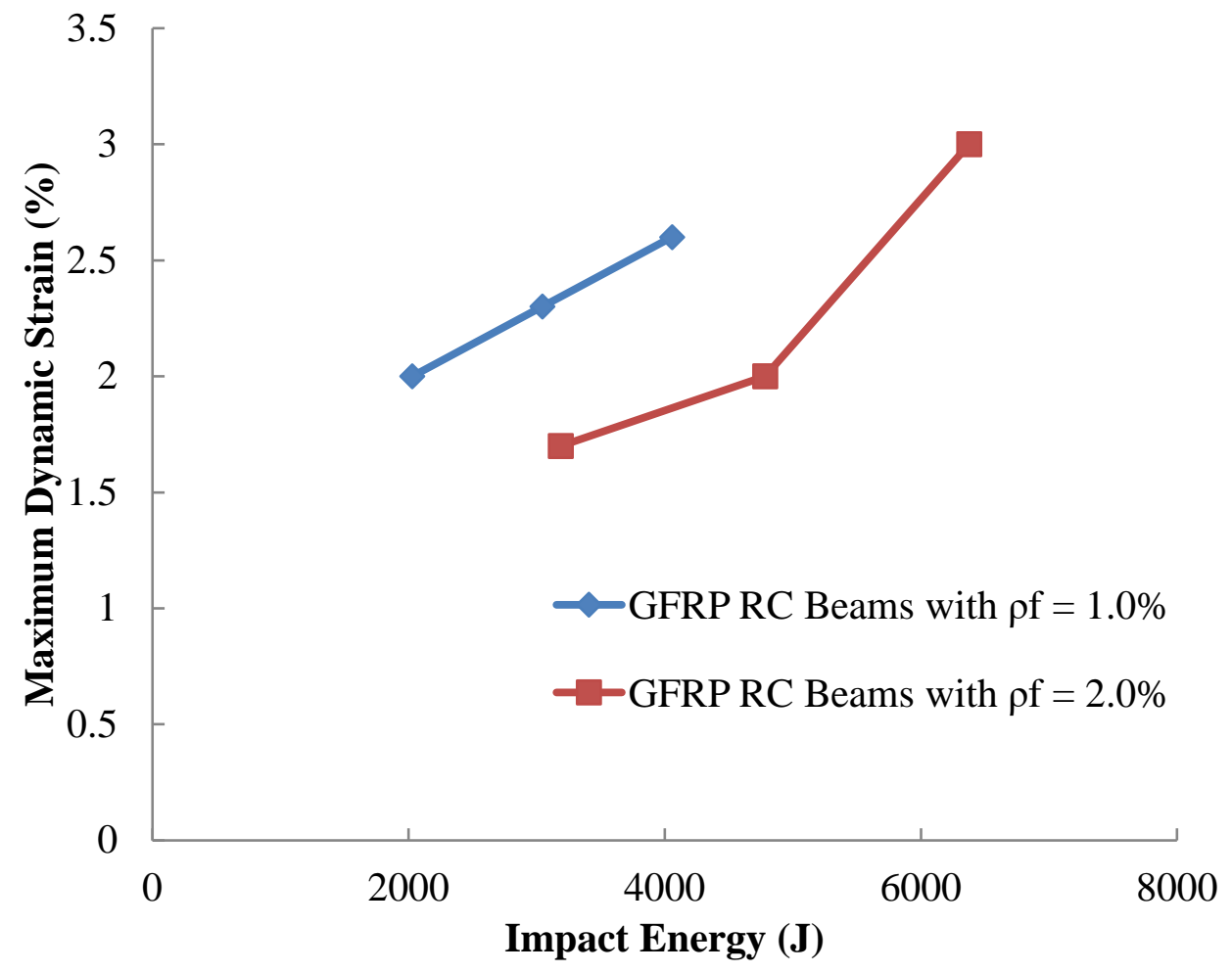

Figure 18. Effect of Impact Energy on Maximum Dynamic Strain 


\section{Static Loading}
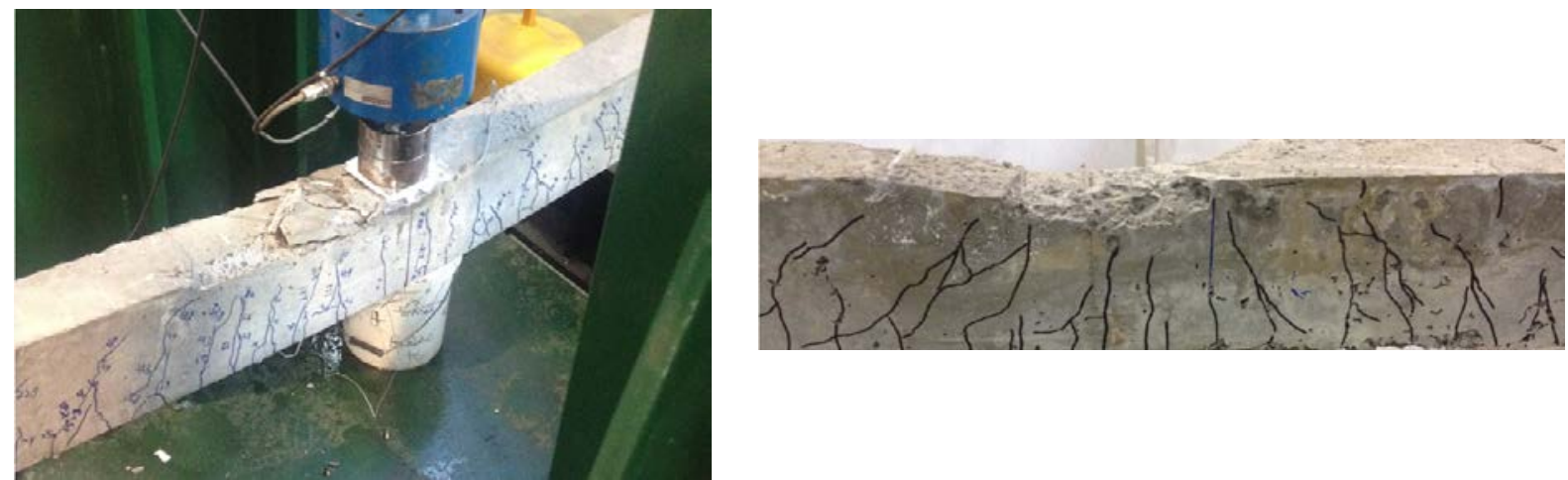

(a) At 50\% Energy Absorption
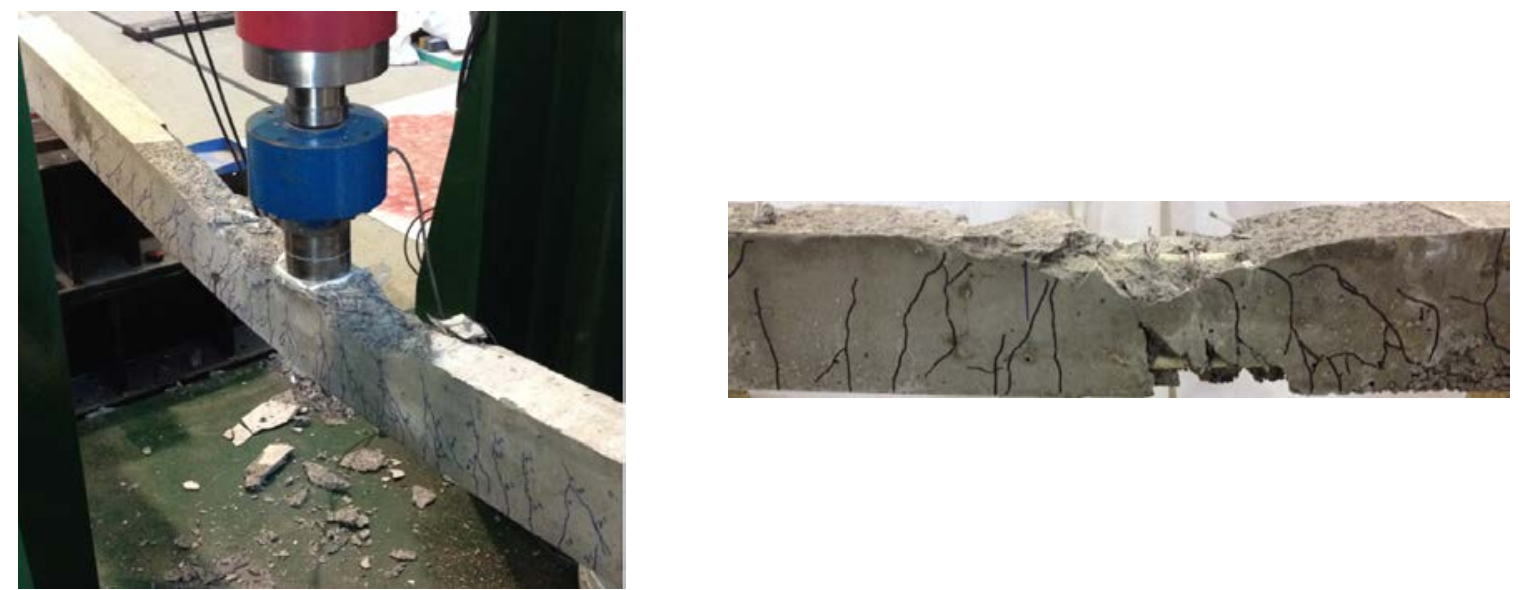

(b) At 75\% Energy Absorption
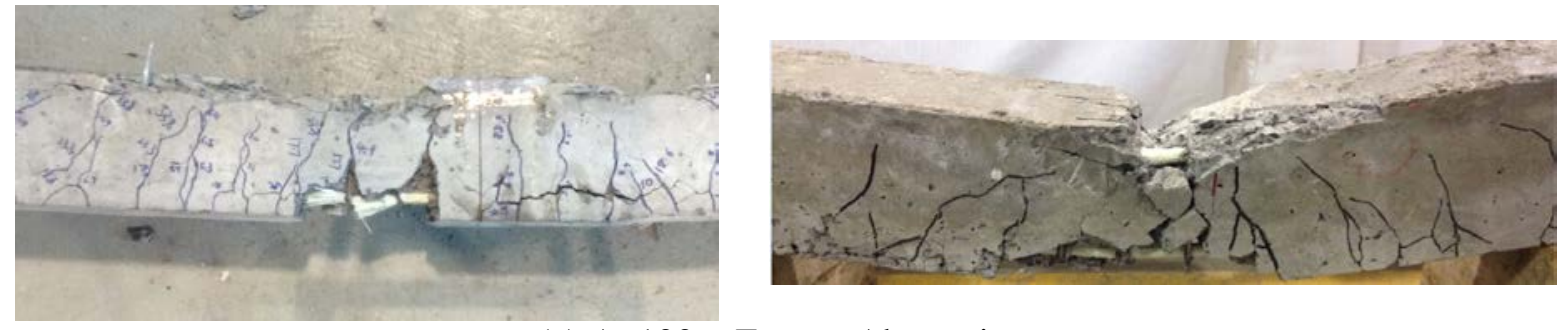

(c) At 100\% Energy Absorption

Figure 19. Failure Modes of GFRP-RC Beams ( $\rho_{f}=1.0 \%$ and ${f^{\prime}}_{c}=120 \mathrm{MPa}$ ) under Static and Impact Loading 


\section{Static Loading}

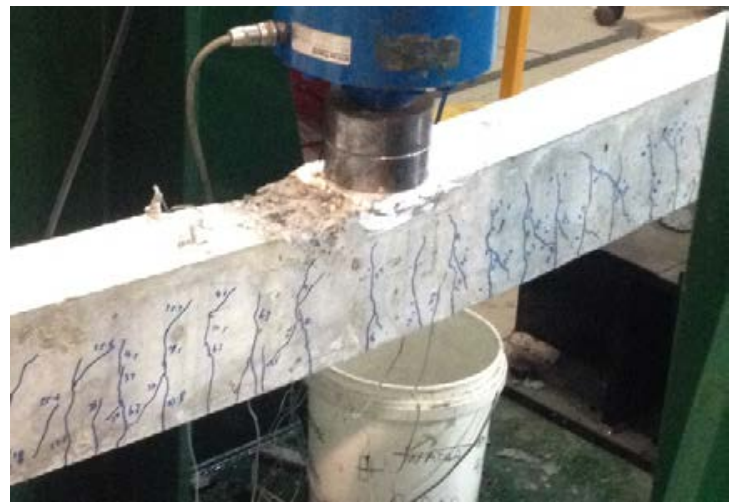

\section{Impact Loading}

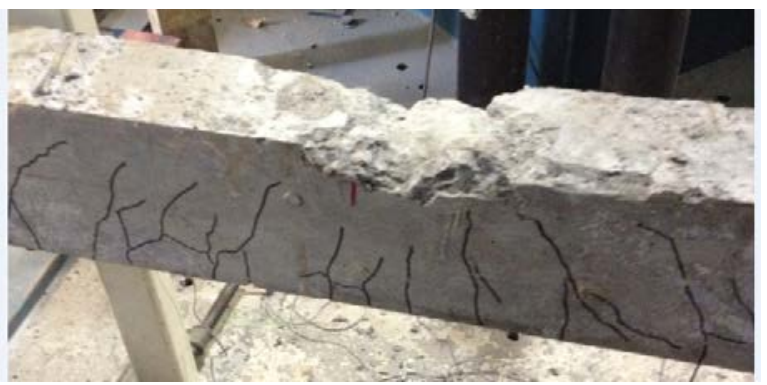

(a) At 50\% Energy Absorption
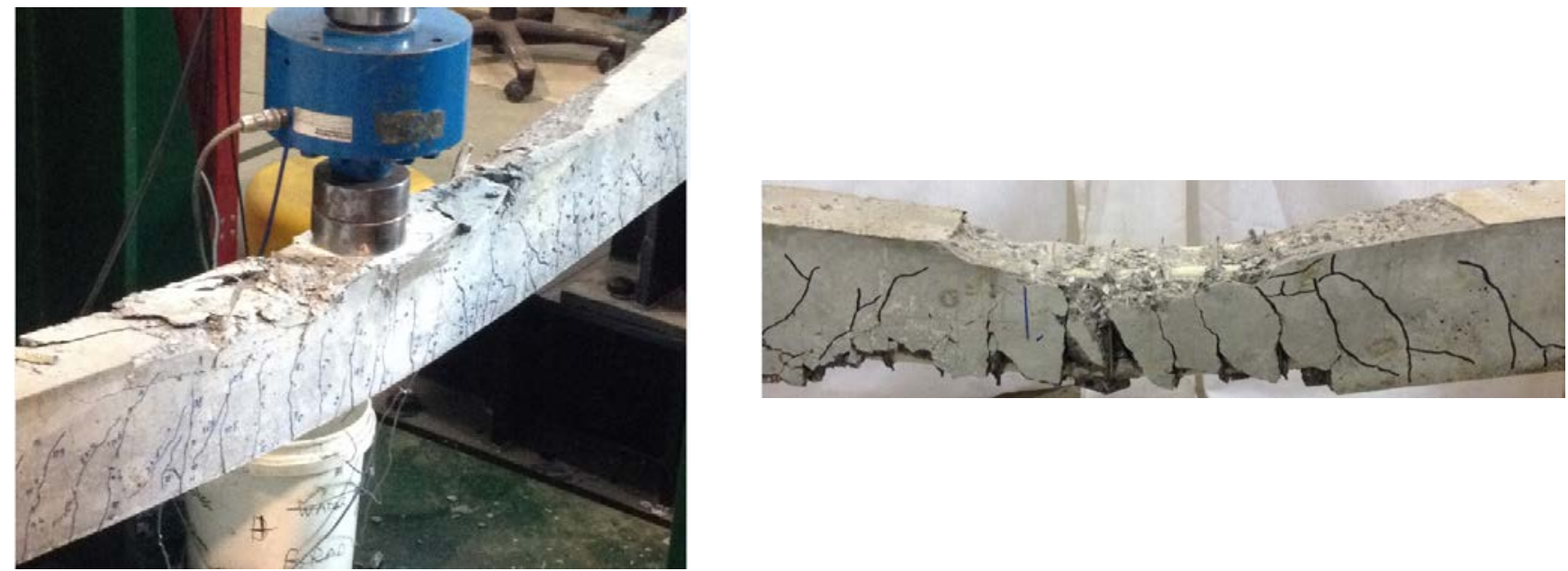

(b) At 75\% Energy Absorption
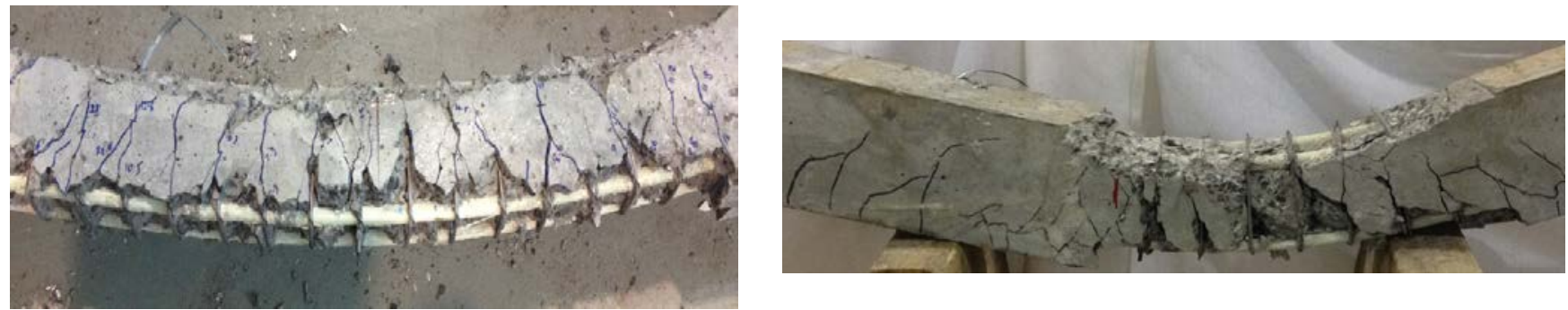

(c) At 100\% Energy Absorption

Figure 20. Failure Modes of GFRP-RC Beams $\left(\rho_{f}=2.0 \%\right.$ and $\left.f^{\prime}{ }_{c}=120 \mathrm{MPa}\right)$ under Static and Impact Loading 


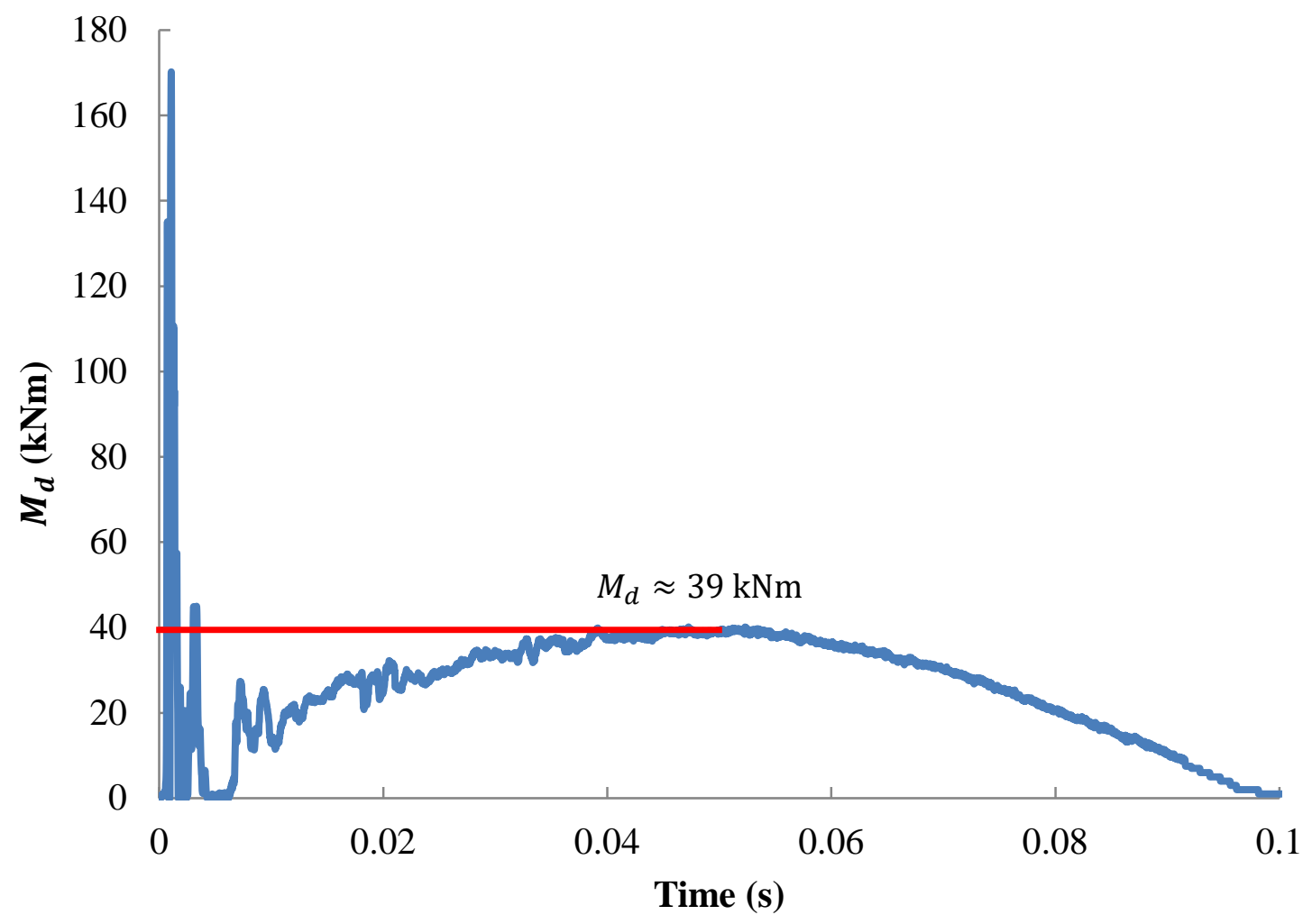

Figure 21. Dynamic Moment -Time History Response of GFRP-RC Beam 120-\#4HM-2.0-I0.825 under Impact Loading 